Año XLIX. urtea

$123-2017$

Urtarrila - ekaina

Enero - junio

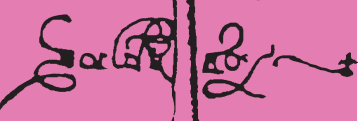

.
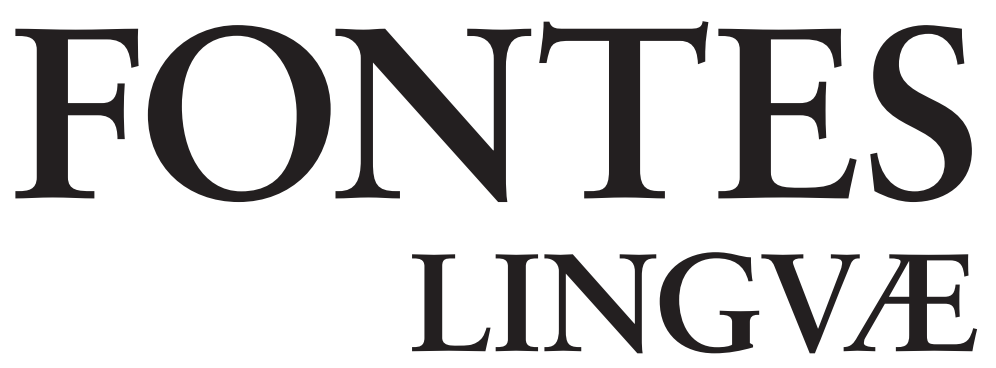

VASCONVM

STVDIA ET DOCVMENTA

SEPARATA

\section{Dardarkari anizkunaren aldakortasunaz}

Iñaki Gaminde, Aintzane EtXebarria, Naia Eguskiza, Asier Romero, Aitor IgLESIAS 


\title{
Dardarkari anizkunaren aldakortasunaz
}

\author{
Sobre la variabilidad de las vibrantes múltiples
}

On the variation in the trill rhotics

Iñaki GAMINDE

Euskal Herriko Unibertsitatea (UPV/EHU)

inaki.gaminde@gmail.com

Aintzane ETXEBARRIA

Euskal Herriko Unibertsitatea (UPV/EHU)

aintzane.etxebarria@ehu.eus

Naia EGUSKIZA

Euskal Herriko Unibertsitatea (UPV/EHU)

eguskiza.n@gmail.com

Asier ROMERo

Euskal Herriko Unibertsitatea (UPV/EHU)

a.romero@ehu.eus

Aitor IGLESIAS

Euskal Herriko Unibertsitatea (UPV/EHU)

aitor.iglesias@ehu.eus

Lan hau «GIU 16/22» (Euskal Herriko Unibertsitatea) eta «IT 1028/16» (Eusko Jaurlaritza) proiektuen barnean egin da. Lan honetako egileak UPV/EHUko EUDIA ikerketa-talde kontsolidatuko kideak dira. 


\section{LABURPENA}

Lan honetan dardarkari anizkunaren alofonoak deskribatzen dira, eta alofonoak erabiltzean aldakortasuna zerk eragiten duen aztertzen da. Horretarako, Euskal Herriko zazpi probintzietako 23 eta 36 urte bitarteko 155 gazteri grabatu zaie bat-bateko testu bat. Era bitako azterketak egin dira; batetik, alofonoak euren artean bereizteko ezaugarri fonetikoak aztertu dira; bestetik, irizpide linguistikoak, geografikoak eta sozialak erabili dira. Datuetatik ondorioztatzen da, hegoaldeko gazteek batez ere dardarkari anizkun apikaria erabiltzen dutela eta iparraldekoek ubularra, gainera, aipatutako dardarkarien alofonoen erabilerari eragiten dioten aldagaiak ezberdinak direla.

Gako hitzak: dardarkari anizkuna; alofonoak; bat-bateko testua; aldagaiak.

\section{RESUMEN}

En este trabajo se describen los alófonos de la vibrante múltiple, y también se analizan las diferentes variables que influyen en la utilización de estos alófonos. Para ello, se ha recogido un corpus de habla espontánea a 155 jóvenes de entre 23 y 36 años de las siete provincias vascas, con grabaciones de un texto. Se han hecho dos tipos de análisis. Por una parte, se han analizado las características fonéticas para diferenciar los alófonos. Por otra parte, se han utilizado criterios lingüísticos, geográficos y sociales. De los datos se infiere que los jóvenes del sur de Euskal Herria peninsular utilizan sobre todo la vibrante apical múltiple y los del norte la vibrante uvular, además, las variables que influyen en la utilización de dichos alófonos son diferentes.

Palabras clave: vibrante múltiple; alófonos; texto espontáneo; variables.

\section{ABSTRACT}

This investigation describes the way how 155 Basque-speaking youngsters from seven Basque Provinces, aged between 23 and 36, use the trilled rhotic allophones and its variants. The empirical basis for this study is a corpus of the transcribed spontaneous speech with recordings of a text. The article is organized as follows. First, we have analyzed the phonetic characteristics to distinguish different allophones. Secondly, we have used linguistic, geographic and social criteria. The results indicate that the youngsters from the Peninsular Southern Basque Country mainly use the trilled apical rhotic and those of the northern part tend to use the uvular rhotic. Finally, it's necessary to indicate that the variables that influence on the use of these allophones can be different.

Keywords: Trill rothic; allophones; spontaneous text; variables. 
1. Sarrera. 2. Corpusa eta metodologia. 3. Datuen azterketa. 3.1. Dardarkari apikaria. 3.2. Alofonoen deskripzioak. 3.3. Alofonoen hedadura. 3.4. Dardarkari ubularra. 3.5. Alofonoen hedadura. 4. ONDORIOAK. 5. ERREFERENTZIAK.

\section{SARRERA}

Gure lan honen helburua bikoitza da; alde batetik, bokalen arteko dardarkari anizkunaren alofonoak deskribatu nahi dira eta, bestetik, euron erabileran aldakortasunari eragiten dioten faktoreak aztertu nahi dira. Dardarkari bakunaren gainean egin genuen (Gaminde, Romero, Eguskiza \& Etxebarria, 2016) gure aurreko lanaren aldean, oraingo honetan bat-bateko testuak erabiliko ditugu; bestalde, informatzaile kopurua ere askozaz handiagoa da.

Euskararen barietate gehienetan dardarkari bi daudela adierazi izan da orain artean egin diren deskripzioetan, bata bakuna eta bestea anizkuna. Salbuespen bakarra zuberera izan da (Mitxelena, 1977; Txillardegi, 1980; Hualde, 2003, besteak beste).

Lan honen helburua da bokalen artean dardarkari anizkunak eduki ditzakeen alofonoak deskribatzea eta aztertzea, horretarako soinuen azterketa akustikoan oinarrituko gara. Aurreko lan batean (Gaminde et al., 2016) dardarkari bakunaren alofonoez jardukeran testu irakurriak erabili genituen, oraingo honetan bat-bateko testuak erabili ditugu. Alofonoen deskripzioarekin batera euren bereizkuntzan garrantzitsuak izan daitezkeen indize akustiko batzuk ere emango ditugu.

Gure aurreko lanean (Gaminde et al., 2016) esaten genuen moduan, artikulazioaren ikuspuntutik dardarkariak kontsonante ahokari ahostunak dira eta mihiaren mugimendu azkarrez egiten dira; batzuetan mihiak airearen ibilbidea itxi dezake une labur batez eta beste batzuetan, ostera, ez da airearen ibilbidea guztiz ixten. Anizkunaren eta bakunaren arteko bereizketa dardarkariak gauzatzeko egiten diren dardar kopuruaren 
arabera egiten da. Horrela bada, dardara bakarra denean bakuna izango da eta bat baino gehiago direnean anizkuna. Hegoaldeko aldaeretan dardarkari biak albeolarrak izaten dira kasu gehienetan. Akustikoki mihiak albeoloetan ukitzen duen bakoitzeko, haizearen ibilbidea guztiz ixten bada, herskariekin gertatzen den bezala, espektrograman zuriune bat ikusiko da.

Orain arte dardarkari anizkuna albeolartzat jotzen izan da eta salbuespentzat hartu da ubularra Iparraldeko barietate batzuetan (Txillardegi, 1980; Zuazo, 1998; Hualde, 2003), Lapurdin eta Nafarroa Beherean batez ere. Gure corpusean hau guztiz aldatuta dago, izan ere, gure Iparraldeko informatzaile guztiek (\% 100) ubularra erabili dute. Aldaketaren lorratzak eta abiada erraz ikus dezakegu. EHHAren (Euskaltzaindia) zorri hitzaren emaitzak aztertzen baditugu, ikusten dugu apikaria 32 (\% 71,11) informatzailek erabili zutela eta ubularra 13k (\% 28,89), Gaminderen azentuaren gaineko lanean (1998) apikaria 22 informatzailek (\% 44,90) erabili zuten eta ubularra 27k (\% 55,10), Epelde-k esaten duen moduan (2014) ehun heldurekin egindako inkesta batzuetan bik baino ez dute apikaria erabili; zaharren artean, berak adierazten duen moduan denetarik topatzen $\mathrm{da}^{1}$. Erabilera hauek beste hizkuntza batzuetan ere gertatzen dira, Chambers eta Trudgill-en (1994) lanean ikusten den moduan, suedieraren informatzaile batzuek biak banaketa osagarrian erabiltzen dituzte. Montoyak (2004) aipatzen du Zugarramurdin eta Urdazubin ere entzun daitekeela noizean behin nahiz erabilera ez den sistematikoa.

Dardarkarien ezaugarrien gainean gehien nabarmentzen dena euron aldakortasuna da (Ladefoged \& Maddieson, 1996; Blecua, 2001, 2008; Bradley \& Willis, 2011; Ortiz de Pinedo, 2012; Fernández Planas, 2013). Blecuak (2001) artikulazioaren erlaxatzearekin lotzen du aldakortasuna.

Gaztelaniarako alofonoak hertsigune kopuruaren arabera sailkatu dira; horrela bi edo hiru hertsigune aipatzen dira (Quilis, 1988, 1993; Fernández Planas, 2013); Quilisek batez bestekoa hiru hertsigunekoa dela esaten du (1993), era berean albeolo atzekotzat jotzen izan da (Fernández Planas, 2013). Egile batzuek lan honetan ikusiko ditugun moduko alofono hurbilkariak (Blecua, 2001; Ortiz de Pinedo, 2012) eta hertsigune bakarrekoak aipatu dituzte (Blecua, 2001; Fernández Planas, 2013) eta baita gauzapen mistoak ere; erdia dardarkaria eta erdia hurbilkaria (Fernández Planas, 2013). Blecuak (2008) adierazten duen moduan dardarkariak osagai herskariak, hurbilkariak eta frikariak eduki ditzake.

Frantsesaren dardarkari ubularraren gainean egineko ikerketetan gauzapenen aldakortasuna da gehien nabarmentzen den ezaugarri bat (Demolin, 2001; Hambye, 2005); azken egile honek Belgikako frantsesa aztertzean 19 alofono deskribatu ditu. Hambyek (2005) aldakortasunaren eragileetan bi aipatzen ditu nagusiki, ingurune fonikoa eta egongune prosodikoa.

1 Xantiana Etchebesteren informazioaren arabera Zuberoan adina da faktore garrantzitsua bien erabileran, gauza bera gertatzen da Garazi aldean Alex Artzelusek emandako informazioaren arabera. 
Gure lan honetan corpusean agertu zaizkigun alofonoak ikertzean era bitako azterketak egingo ditugu. Batetik, alofonoak euren artean bereizteko irizpide (fonetiko) akustikoak erabiliko ditugu, horretarako iraupenaren eta energiaren gainean hartutako neurriak erabiliko ditugu. Bestetik, alofonoen aldakortasuna arazo konplexua izanik, hiru eratako irizpideak erabiliko ditugu: linguistikoak, geografikoak eta sozialak. Irizpide linguistikoetan kontuan hartuko ditugu aurreko silabaren kontsonante eta bokal motak euren eragina edo eragin eza agirian uzteko eta dardarkaria gauzatzen den talde prosodikoaren abiada. Irizpide sozialetan informatzaileen generoaren eta ama hizkuntzaren eragina ere aztertuko da.

Dardarkari anizkuna fonema bakartzat jotzen bada ere, beraren gauzapena eta alofonoak eragile batzuen eraginpean daude. 1. irudiko eskeman eragile horiek osatzen duten azpi-sistemak irudikatzen dira.

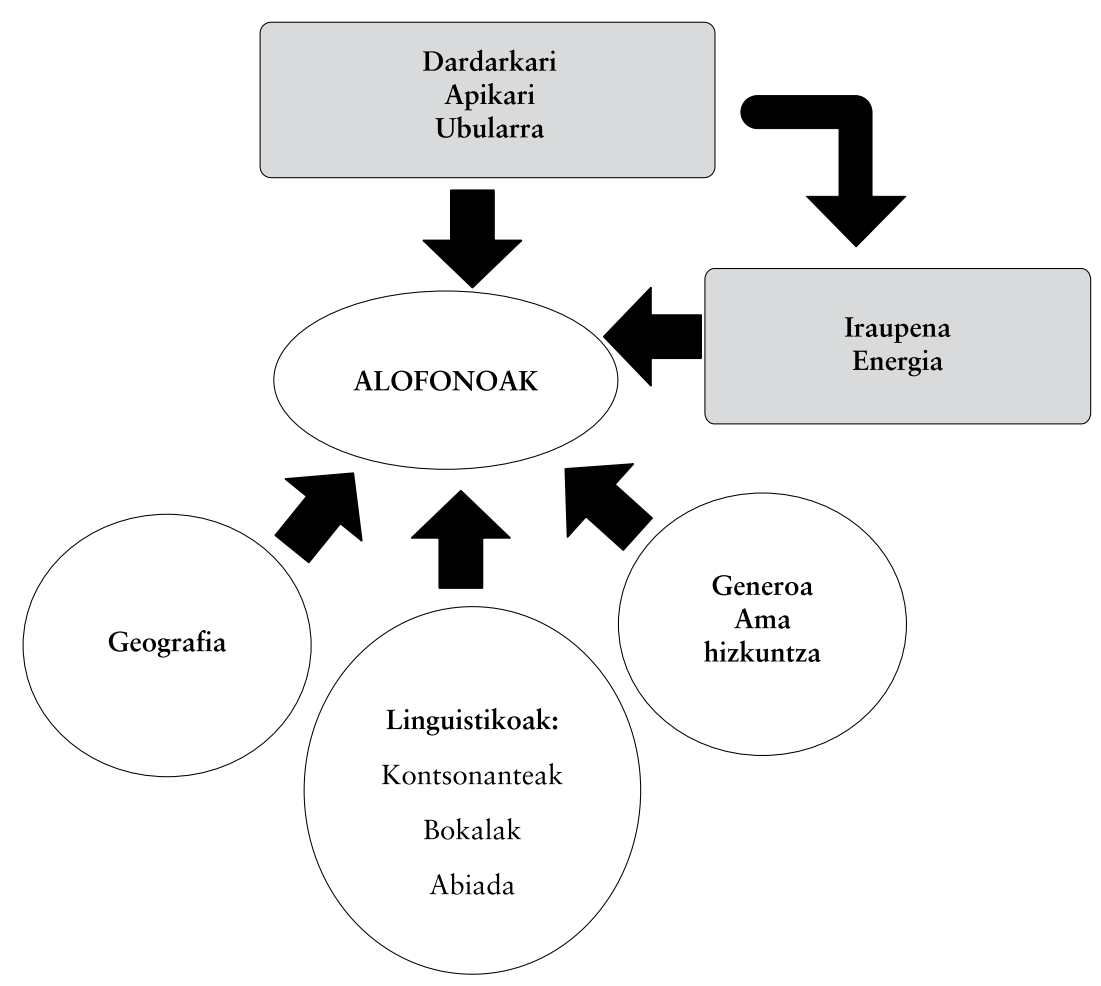

1. irudia. Dardarkari anizkunaren alofonoei eragiten dieten azpi-sistemak.

Lana lau atal nagusitan banatuta aurkezten dugu, sarrera honen osteko bigarren atalean lana burutzeko erabili den metodologia aurkeztuko dugu, hirugarren atalean datuen azterketaren emaitzak emango ditugu. Azkenik, laugarren atalean lortu ditugun ondorio nagusiak laburbilduko ditugu. 


\section{CORPUSA ETA METODOLOGIA}

Atal hau zati bitan banatuta aurkeztuko dugu; lehen zatian datuak jasotzeko erabili dugun metodologia azalduko dugu eta bigarren zatian, berriz, datuak aztertzeko metodologia.

Gure lanerako corpusa osatu ahal izateko 155 informatzaile izan ditugu; informatzaileei sei irudiko komiki bat eman ondoren, denbora tarte bat eman zitzaien istorioa ulertzeko eta gero kontatzeko eskatu zitzaien lagunartean egingo zuketen moduan.

Informatzaileen ezaugarrien arabera hiru talde egin daitezke (AN), (AM) eta (BN). (AN) taldeko informatzaile guztiak neskak dira eta euron ama hizkuntza euskara izan da, gaztelania edo frantsesa eskolan eta kalean ikasi dute. Denetara 100 izan dira: Araban 1, Bizkaian 24, Gipuzkoan 35, Nafarroa Garaian 16, Lapurdin 10, Nafarroa Beherean 10 eta Zuberoan 4. 1. taulan probintziaka sailkatuta agertzen da nongoak izan diren.

1. taula. AN taldeko informatzaileen jatorrizko herriak.

\begin{tabular}{|c|c|}
\hline Probintzia & Informatzaileak \\
\hline Araba & Aramaio \\
\hline Bizkaia & $\begin{array}{l}\text { Mungia, Bakio, Lezama, Larrabetzu, Lemoa, Igorre, Zeanuri, Bermeo, Busturia, Gernika, } \\
\text { Morga, Ea, Ereño, Amoroto, Munitibar, Ondarroa, Berriatua, Markina, Zornotza, } \\
\text { Abadiño, Atxondo, Elorrio, Berriz eta Mallabia }\end{array}$ \\
\hline Gipuzkoa & $\begin{array}{l}\text { Mutriku, Deba, Elgoibar, Eibar, Bergara, Arrasate, Aretxabaleta, Oñati, Zumaia, } \\
\text { Aizarnazabal, Zarautz, Orio, Zestoa, Azkoitia, Azpeitia, Errezil, Beizama, Urretxu, } \\
\text { Gabiria, Beasain, Ordizia, Segura, Ataun, Zaldibia, Tolosa, Zizurkil, Andoain, Lasarte, } \\
\text { Hernani, Donostia, Lezo, Orereta, Oiartzun, Hondarribia eta Irun }\end{array}$ \\
\hline Nafarroa G. & $\begin{array}{l}\text { Urdiain, Arbizu, Lakuntza, Lizarraga, Arruitz, Lekunberri, Atallu, Leitza, Goizueta, } \\
\text { Ezkurra, Zubieta, Oronoz, Irurita, Sunbilla, Lesaka eta Bera }\end{array}$ \\
\hline Lapurdi & $\begin{array}{l}\text { Hendaia, Azkaine, Ziburu, Donibane, Ezpeleta, Larresoro, Uztaritze, Mugerre, Hazparne } \\
\text { eta Itsasu }\end{array}$ \\
\hline Nafarroa B. & $\begin{array}{l}\text { Aiherra, Isturitze, Oragarre, Donapaleu, Arhantsusi, Izura, Larzabale, Garazi², Irulegi eta } \\
\text { Baigorri }\end{array}$ \\
\hline Zuberoa & Urdiñarbe, Atharratze, Maule eta Barkoxe \\
\hline
\end{tabular}

AM taldeko informatzaileak euskara ama hizkuntzatzat eduki duten mutilak dira, hauek ere frantsesa eta gaztelania etxetik kanpo ikasi dute; denetara 25 izan dira; Bizkaian 6, Gipuzkoan 9, Nafarroa Garaian 4, Lapurdin 2, Nafarroa Beherean 3 eta Zuberoan 1 (2. taula). 
2. taula. AM taldeko informatzaileen jatorrizko herriak.

\begin{tabular}{|l|l|}
\multicolumn{1}{c|}{ Probintzia } & \multicolumn{1}{c|}{ Informatzaileak } \\
Bizkaia & Areatza, Aulesti, Bermeo, Gernika, Iurreta eta Ondarroa \\
\hline Gipuzkoa & Arrasate, Amezketa, Azpeitia, Beasain, Deba, Donostia, Hondarribia, Tolosa eta Zumarraga \\
\hline Nafarroa G. & Arbizu, Bera, Donamaria eta Leitza \\
\hline Lapurdi & Azkaine eta Hazparne \\
\hline Nafarroa B. & Armendaritze, Baigorri eta Gabadi \\
\hline Zuberoa & Barkoxe \\
\hline
\end{tabular}

Azkenik BN taldea ama hizkuntzatzat gaztelania edo frantsesa eduki duten neskek osatzen dute, euskara hezkuntzan txikitatik jaso dute denek. Talde honetan 30 informatzaile izan ditugu: Araban 6, Bizkaian 6, Nafarroa Garaian 6, Lapurdin 3 eta Nafarroa Beherean 3 (3. taula).

3. taula. BN taldeko informatzaileen jatorrizko herriak.

\begin{tabular}{|l|l|}
\multicolumn{1}{c|}{ Probintzia } & \multicolumn{2}{c|}{ Informatzaileak } \\
\hline Araba & Agurain, Artziniega, Eskuernaga, Gasteiz, Kanpezu eta Urizaharra \\
\hline Bizkaia & Balmaseda, Bilbo, Portugalete, Lemoa, Gernika eta Abadiño \\
\hline Gipuzkoa & Deba, Donostia, Elgoibar, Irun, Ordizia eta Tolosa \\
\hline Nafarroa G. & Lesaka, Iruñea, Iturgoien, Irunberri, Erriberri eta Tutera \\
\hline Lapurdi & Azkaine, Baiona eta Itsasu \\
\hline Nafarroa B. & Garazi, Larzabale eta Lukuze \\
\hline
\end{tabular}

Talde guztietako informatzaileek euskaraz burutu dituzte euren ikasketak unibertsitatera arte. Euren adinei dagokienez, esan behar da denak 1981-1994 urte bitartean jaiotakoak izan direla.

Testu guztiak grabatu egin ziren eta horretarako grabagailu batzuk erabili ziren, Sony Minidisc, Marantz PMD620 eta ZoomH4n izan dira; batzuetan ordenagailuan zuzenean grabatu dugu USB mikrofono baten bidez. Grabazioak UPV/EHUren fakultate batzuetan egin dira, baita informatzaileen herrietan ere, dela euren etxeetan, dela eurek bilatutako lokaletan.

Seinaleen etiketazioa, soinuen transkripzioak eta euron neurriak hartzeko Praat ${ }^{3}$ izeneko programa erabili da (Boersma \& Weenink, 2016), behin transkripzioak eginez

3 Programa hau http://www.fon.hum.uva.nl/praat helbidean eskura daiteke, doan. 
gero, corpusean 49852 soinu batu dira. Horietatik bokalen arteko dardarkariak 2175 dira (\% 4,36); dardarkari anizkunak denetara 501 dira, hau da soinu guztien \% 1 eta dardarkarietan \% 23,03. Markak ipintzean kontuan hartu da hertsigunearen hasiera lehena ipintzeko eta bokalaren hasiera bigarrena ipintzeko. Gure azterketa honetarako bokalen arte hauek baino ez ditugu aztertu.

Soinuen deskripzio zehatza egiteko eta neurriak hartu ahal izateko, banan-banan aztertu, etiketatu eta neurtu dira. Azterketa eta etiketazioa egindakoan, neurri batzuk automatikoki lortu dira praaterako egindako script baten bidez (Lyko, 2008), beste neurri batzuk, berriz, eskuz. Datuen azterketaren gaineko atalean erakutsiko den bezala, hartu diren neurriak soinuen iraupenari eta energiari dagozkienak dira. Soinu guztien iraupen osoak kalkulatu dira eta hertsigune bat baino gehiago dauzkatenen kasuan hertsiguneen eta bokal uneen neurriak ere hartu dira.

Energiari dagokionez, kontsonante bakoitzeko hiru neurri hartu ditugu, kontsonantearen hasieran, energiaren beherengo puntuan eta gero kontsonantearen amaieran (2. irudia). Informatzaile desberdinen datuak erkatu ahal izateko, ehunekoak kalkulatu dira normalizatzeko; horrela, bada, hasierako puntutik beherengo puntura dagoen aldea ehunekoetan ematen da, eta berdin beherengo puntutik amaiera arte dagoen aldea ere.

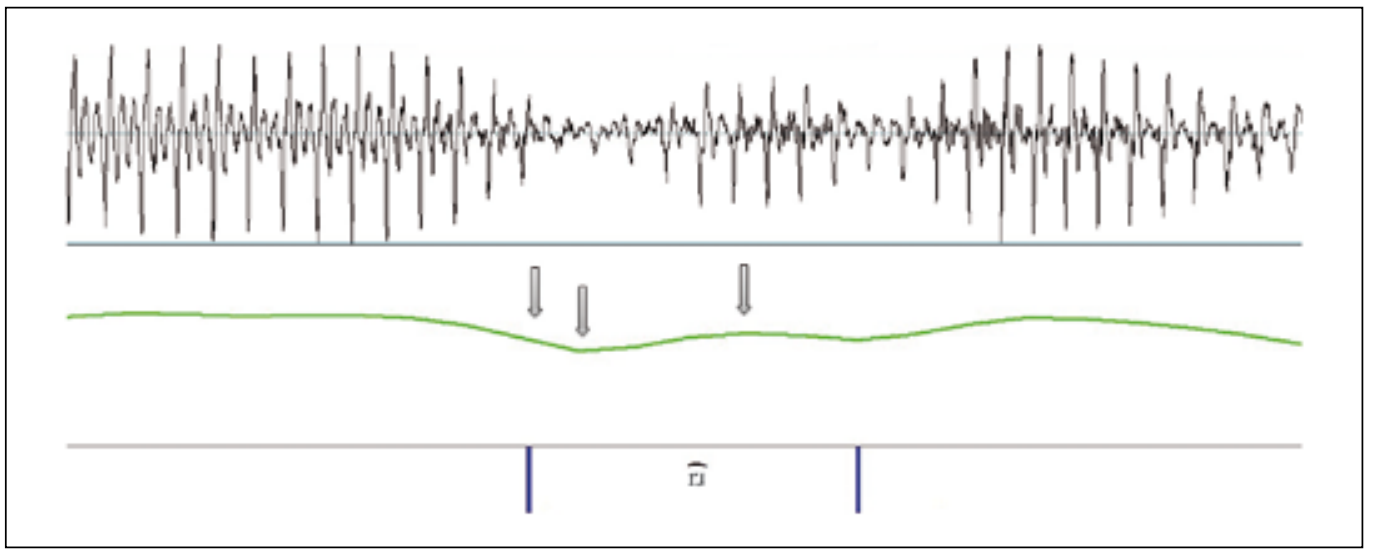

2. irudia. Energia neurtzeko hartu diren puntuak.

Bestalde, alofonoen hedadurari dagokionez, hiru eratako irizpideak erabiliko ditugu: linguistikoak, geografikoak eta sozialak. Irizpide fonikoetan kontuan hartuko dugu aurreko silabaren kontsonante motak edo kontsonante ezak eragina daukaten; era berean, aurreko silabaren bokalen tasunek alofonoen erabileran eragina daukaten ikusiko dugu. Aukeratu ditugun tasunak \pm aurrekoa eta \pm goikoa izatea izango dira. Azkenik, hizketa abiadaren eragina ere kontuan hartuko dugu. Abiada kalkulatzeko talde prosodikoen denbora neurtu da eta silaba kopurua kontatu da, gero kalkulatu da zenbat silaba egiten diren segundoko. 


\section{DATUEN AZTERKETA}

Atal honetan dardarkari apikarien eta ubularren datuen azterketa aurkeztuko dugu; bai batzuekin, bai besteekin alofonoen deskripzioa eta euron hedadura aztertuko da. Datuen azterketa errazago aurkezteko atal hau azpi-atal bitan banatuta emango dugu; lehen azpi-atalean dardarkari apikariari dagozkion datuak emango ditugu eta bigarrenean, berriz, ubularrari dagozkionak.

\subsection{Dardarkari apikaria}

Gure corpusean bokalen arteko dardarkari apikariak 328 izan dira, hau da, dardarkari anizkun guztien \% 65,47.

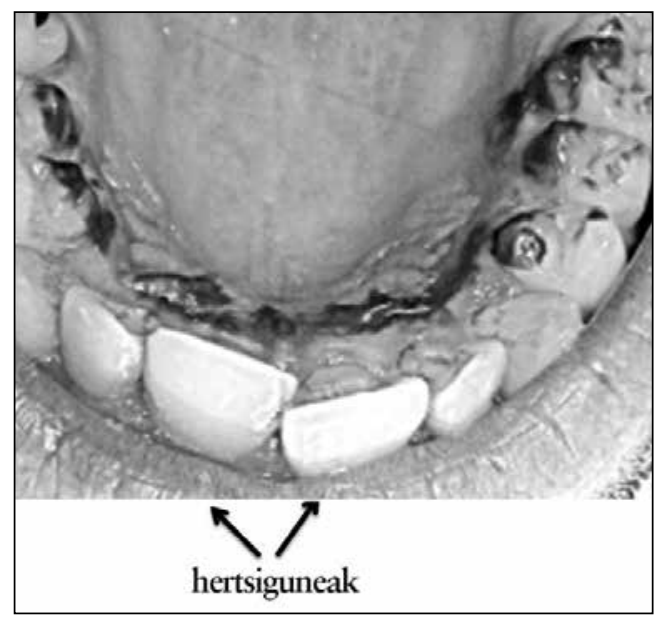

3. irudia. Mihiaren ukitze gunea $[\mathrm{r}]$ egitean.

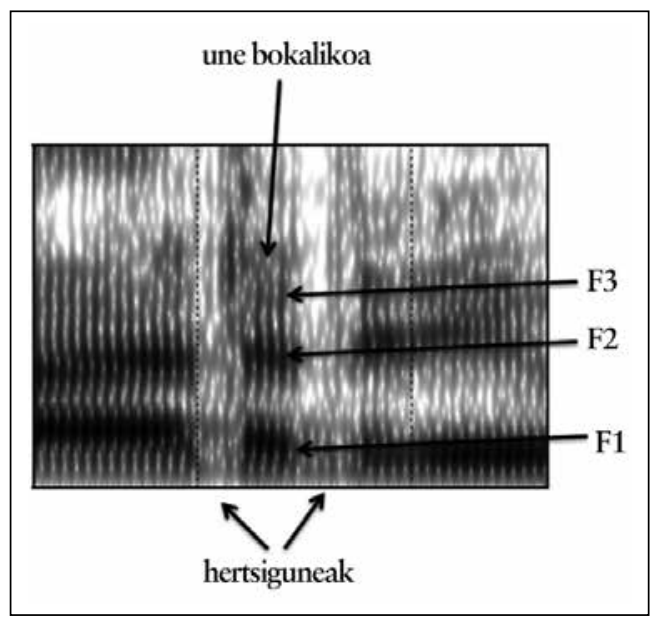

4. irudia. [r] ren hertsiguneak, une bokalikoa eta formakinak, arra.
Artikulatorioki, [r] dardarkari albeolar anizkuntzat jotzen izan da (Txillardegi, 1980; Pagola, 1992; Hualde, 2003; Oñederra, 2004). Ebakitzean dar-dar bat baino gehiago egiten ei da; 3 . irudiko palatograman mihiak albeoloetan uzten duen lorratza ikus daiteke.

Azpi-atal hau sekzio bitan banatuta aurkezten dugu; lehen sekzioan alofonoen deskripzioarekin batera indize akustikoen emaitzak emango dira, bigarrenean, gorago aipatu diren irizpideen arabera alofonoen hedadura aztertuko da.

\subsection{Alofonoen deskripzioak}

Akustikoki dardarkari anizkun honen alofono batzuen espektrogrametan ikus daitekeen bezala (4. irudiko espektrograma), mihiak albeoloetan ukitzen duen bakoitzeko hertsigune bat gertatzen da, hertsiguneen artean une bokaliko bat geratzen da bere formakinekin.

Era honetako alofonoak sailkatzeko erabil daitekeen irizpide bat hertsigune kopurua izan daiteke (Gaminde, 2006, 2007); honen arabera [r2] hertsigune bikoa izango litzateke (5. irudiko espektrograma). Espektrograman ikus daitekeen moduan bokal gunearen aurretxoan zarata banda bat agertzen da bigarren 
formakinaren ingurutik gora. Energiari dagokionez hertsiguneetan txikiagoa da bokal gunean baino (6. irudiko espektrograma).

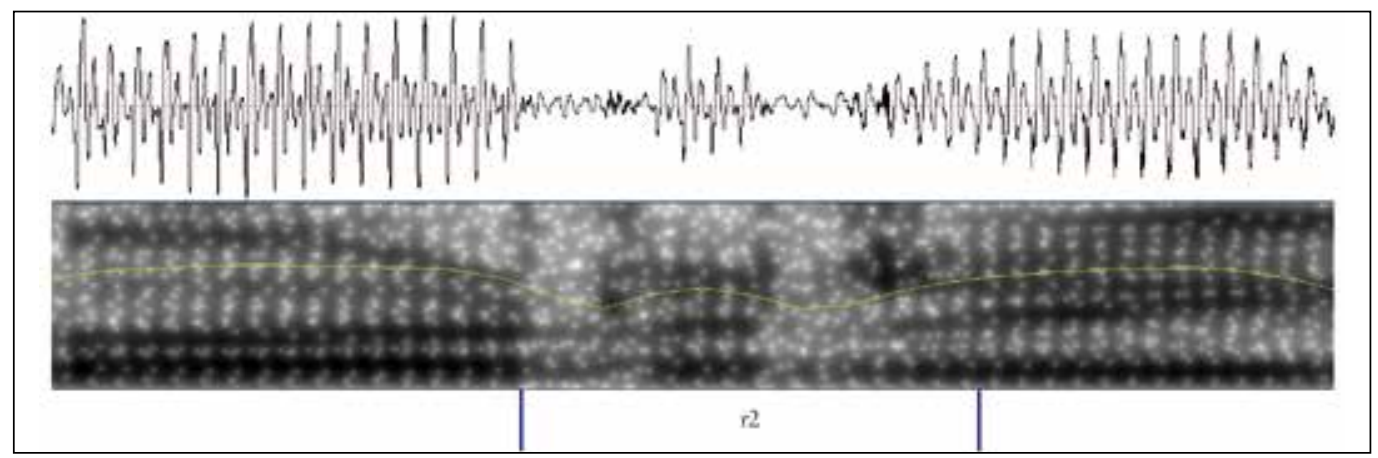

5. irudia. Hertsigune biko dardarkari apikaria (Berriz, A taldeko neska, korrikan).

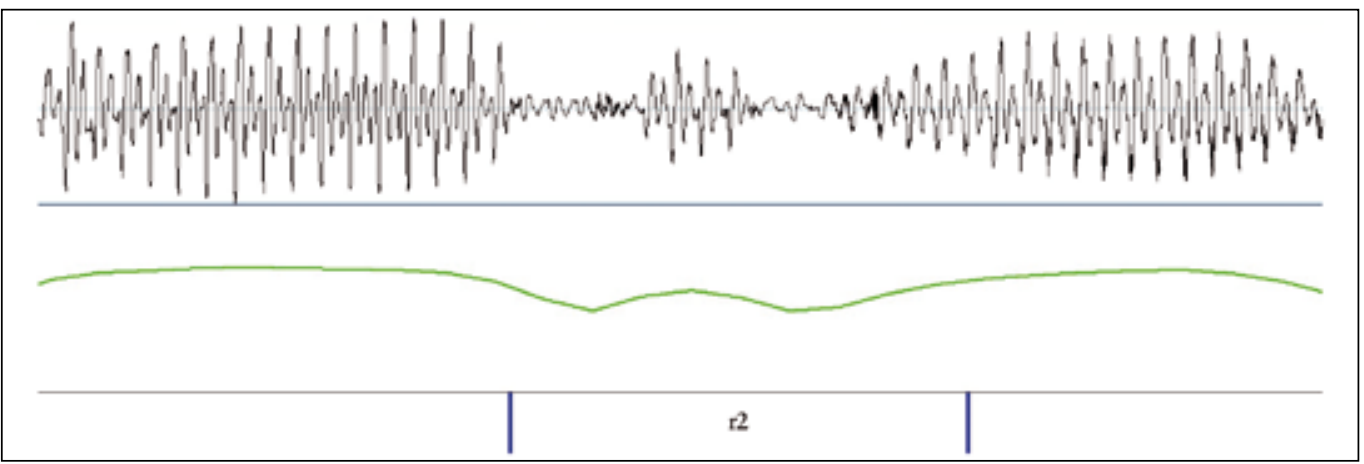

6. irudia. Hertsigune biko dardarkariaren energiaren ibilbidea (Berriz, A taldeko neska, korrikan).

Hiru hertsiguneko alofonoa, [r3] 7. irudiko espektrograman erakusten da. Hemen ere bokal gunearen aurretik zarata banda estu bat ikus daiteke; energiari dagokionez, hertsiguneetan txikiagoa da bokal uneetan baino (8. irudiko espektrograma).

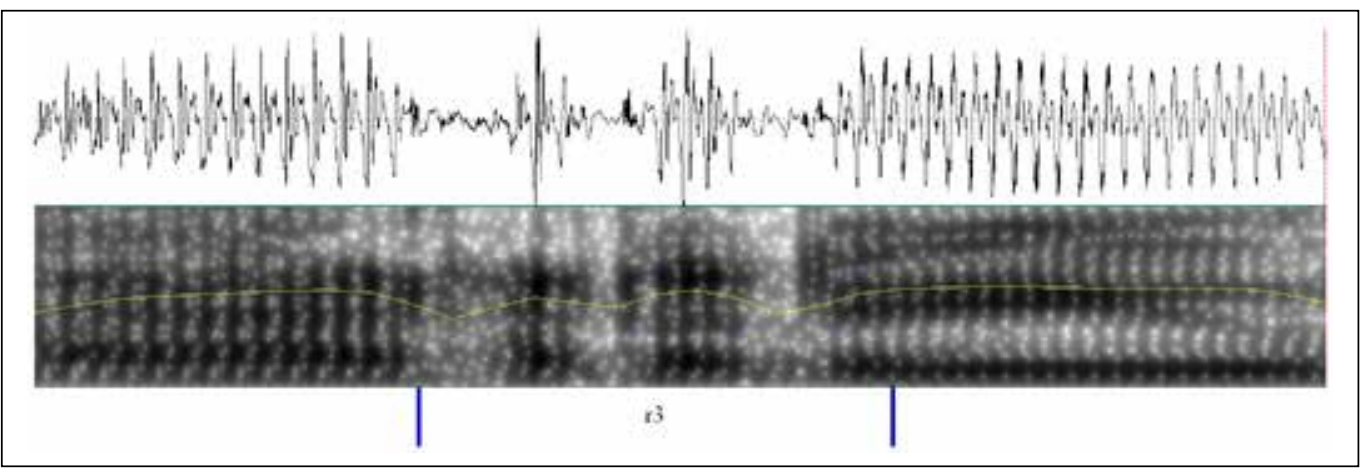

7. irudia. Hiru hertsiguneko dardarkari apikaria (Abadiño, A taldeko neska, arri bat). 


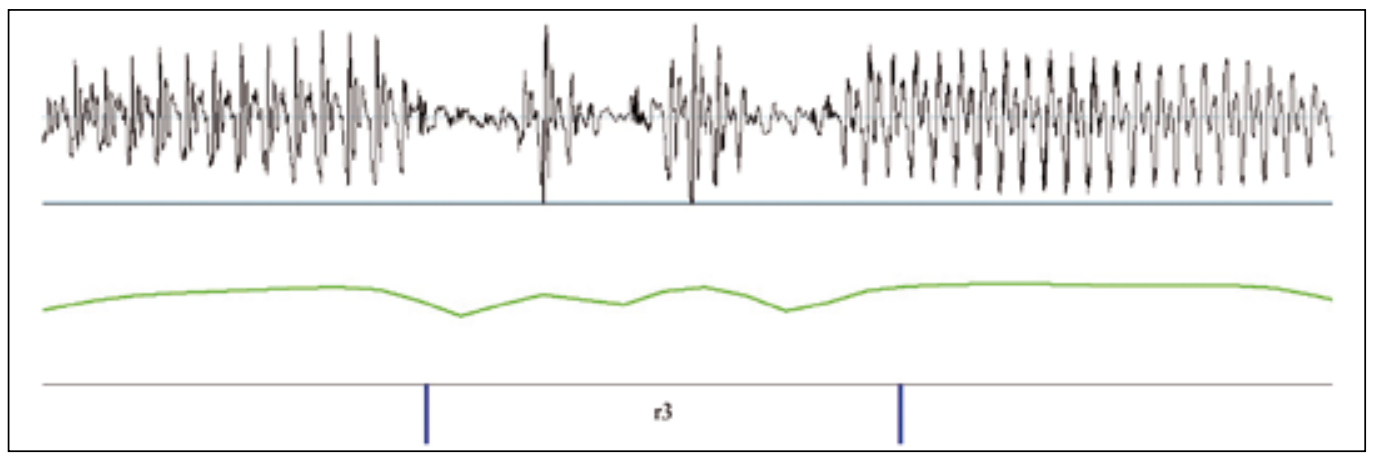

8. irudia. Hiru hertsiguneko dardarkariaren energiaren ibilbidea (Abadiño, A taldeko neska, arri bat).

Azkenik, corpusean agertu zaigun lau hertsiguneko adibide bakarra ematen dugu 9. irudiko espektrograman; energiaren ibilbidea 10. irudiko espektrograman ikus daiteke.

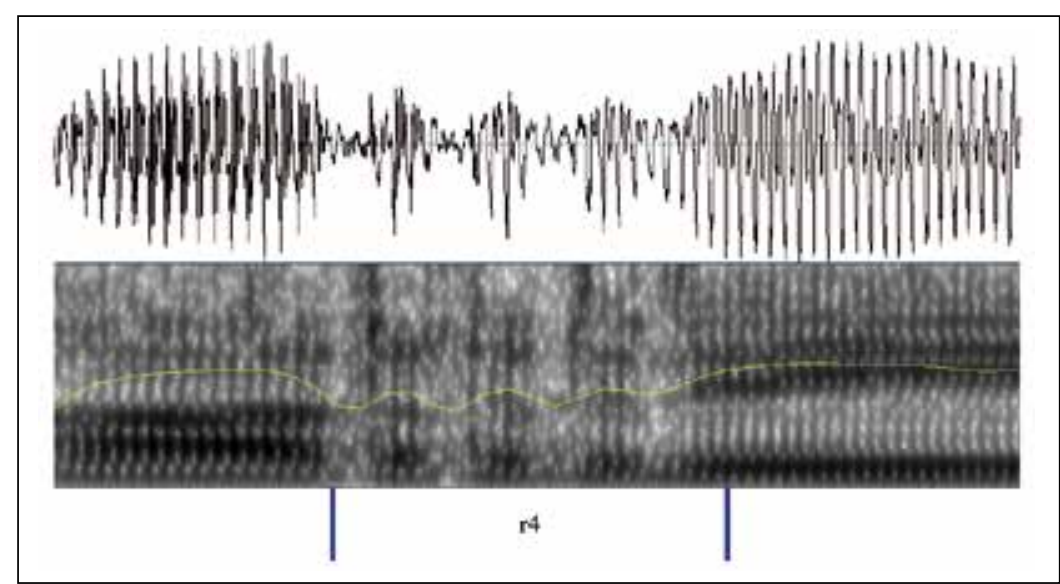

9. irudia. Lau hertsiguneko dardarkari apikaria (Beasain, A taldeko neska, jarri).

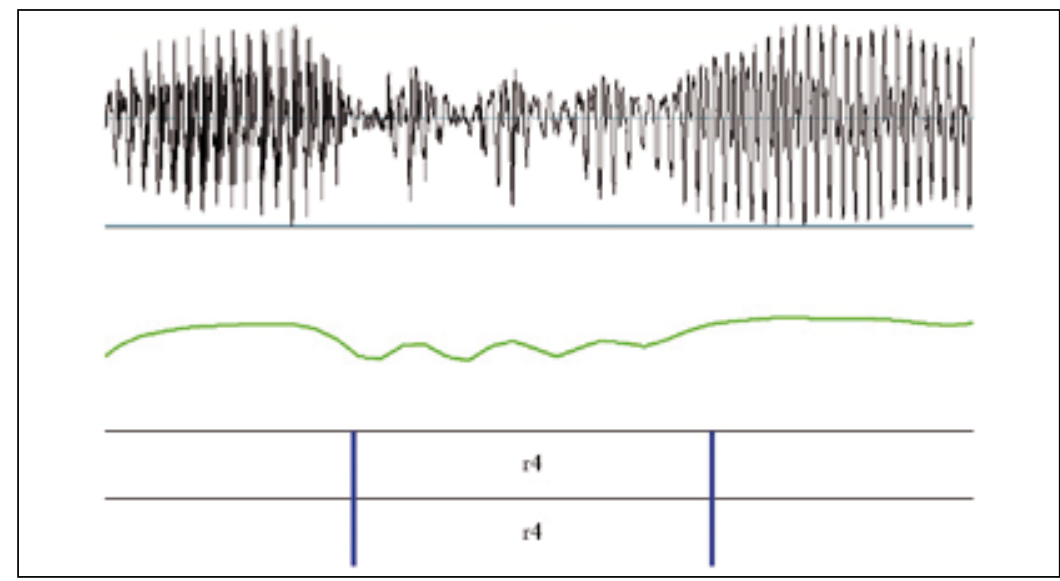

10. irudia. Lau hertsiguneko dardarkariaren energiaren ibilbidea (Beasain, A taldeko neska, jarri). 
Bakoitzaren kopuruei bagagozkie, [r2] ugariena da (164, \% 50), gero [r3] $(28, \% 8,54)$ eta azkenik [r4] (1, \% 0,30).

Badira hertsigune bakarra daukatenak ere, hertsigunearen ostean bokal unea agertzen da, sarritan ondoko bokalaren hasieratik bereiztea zaila izaten da. Molde hau adierazteko [r.] ikurra aukeratu dugu (11. irudiko espektrograma); energiari dagokionez, hertsigunean txikiagoa da bokal unean baino (12. irudiko espektrograma).

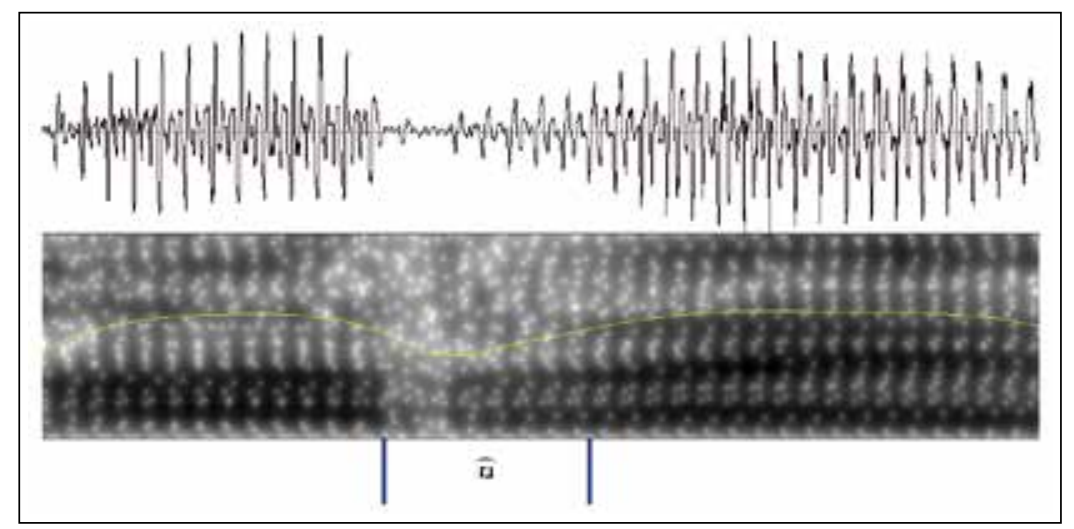

11. irudia. [ิ [r.] alofonoa (Orio, A taldeko neska, jarri).

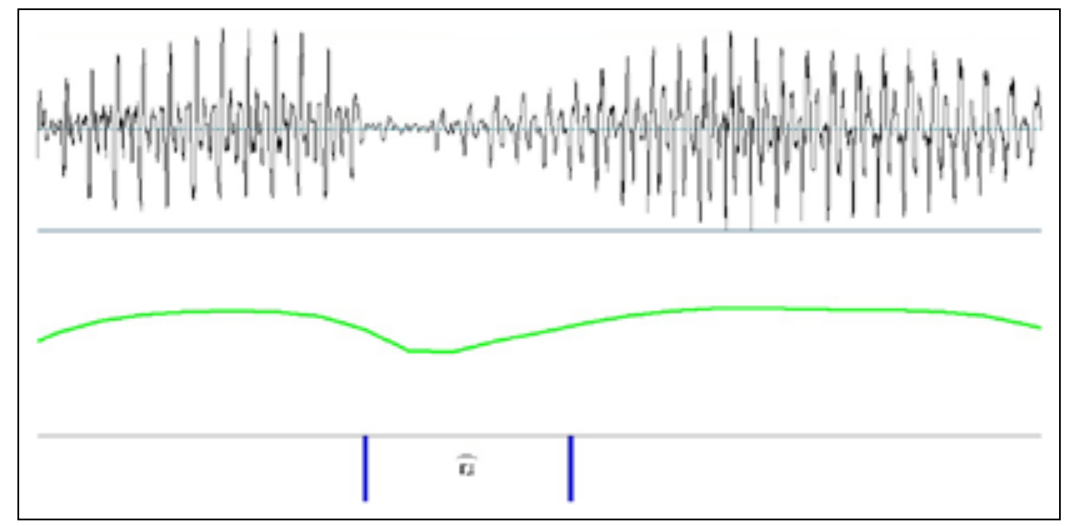

12. irudia. [ [r.] alofonoaren energiaren ibilbidea (Orio, A taldeko neska, jarri).

Hertsigunearen osteko bokal unearekin batera zarata ager daiteke (13. irudiko espektrograma), honelako kasuetan $\left[\widehat{\mathrm{r}_{I}}\right]$ erabiliko dugu; energiari dagokionez, esan behar dugu apalduz doala bigarren uneraino (14. irudiko espektrograma). Gure corpusean

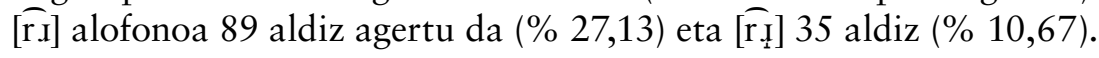




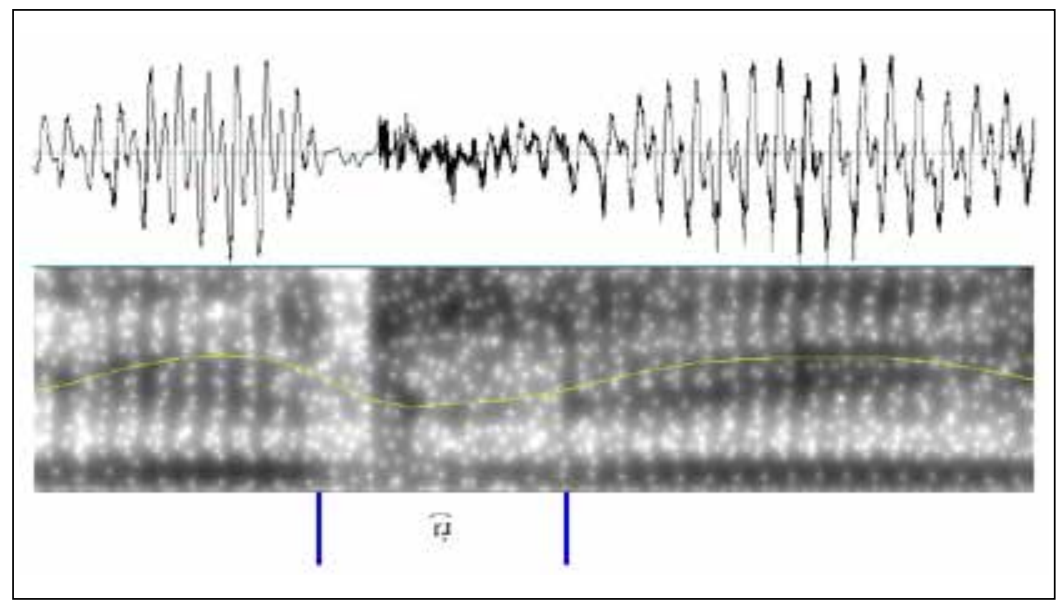

13. irudia. [ [rI] $]$ alofonoa (Ezkurra, A taldeko neska, irristatu).

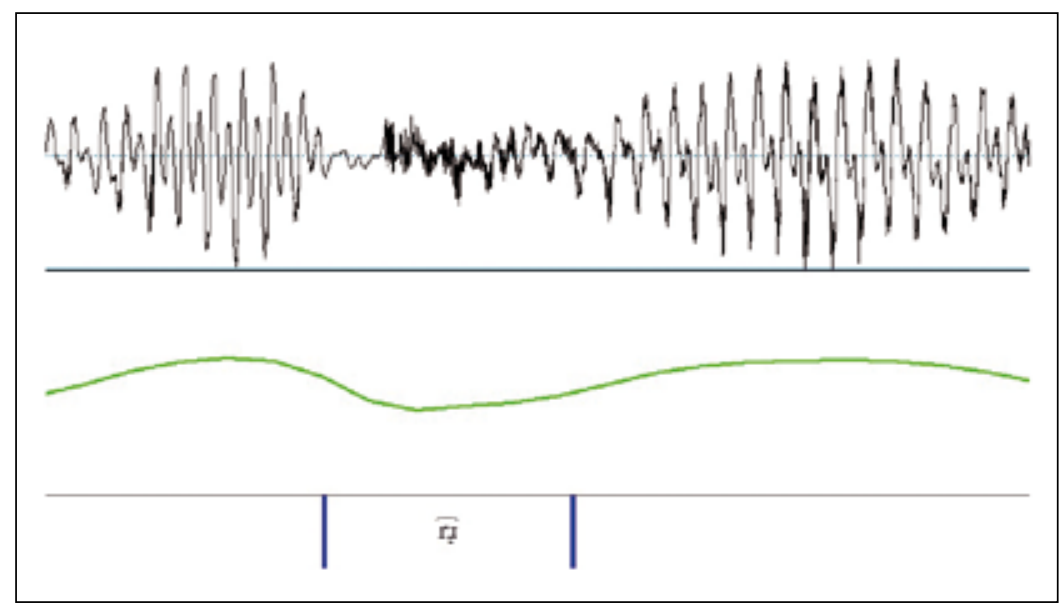

14. irudia. $[\widehat{[} \bar{I}]$ alofonoaren energiaren ibilbidea (Ezkurra, A taldeko neska, irristatu).

Alofono batzuetan aldameneko bokalen formakinak hertsiguneetan zehar agertzen dira argi, horrelakoetan hurbilkaritzat jo behar dira; hala ere, bokal unea, hertsiguneen aldean, ondo nabarmentzen da batzuetan (15. irudiko espektrograma). Beste batzuetan hertsiguneak eta bokal guneak nahasirik agertzen dira (17. irudiko espektrograma). Lehen kasuan [r 2 2] ikurra erabili dugu eta bigarrenean $[\underset{r}{\mathrm{r}}]$. Kasu bietan energia apalagoa da kontsonantean aldameneko bokaletan baino (16. eta 18. irudiak). 


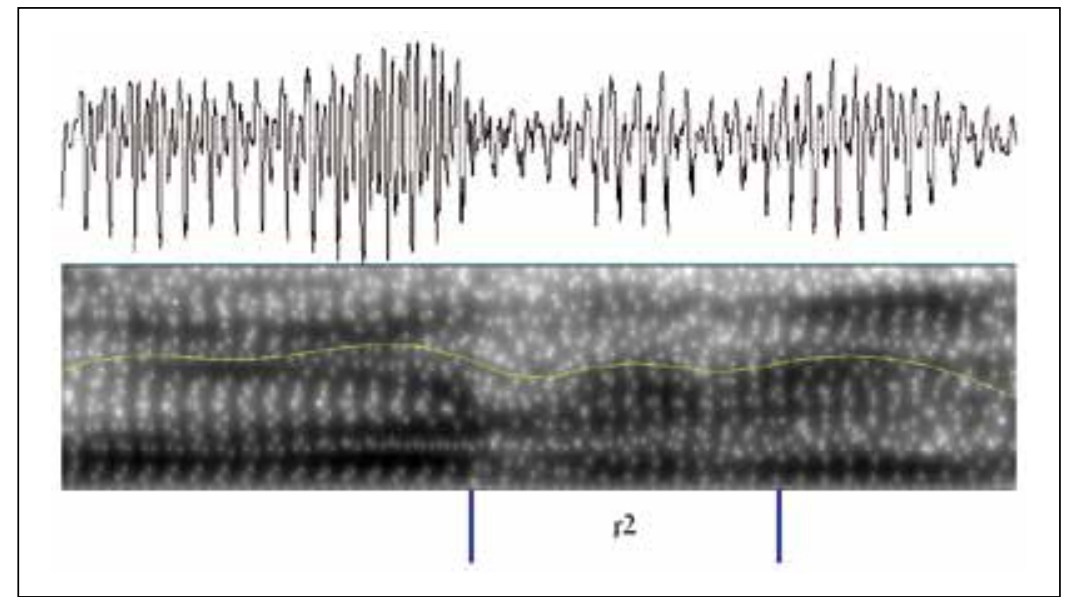

15. irudia. [ṛ 2] alofono hurbilkaria (Atxondo, A taldeko neska, korrika).

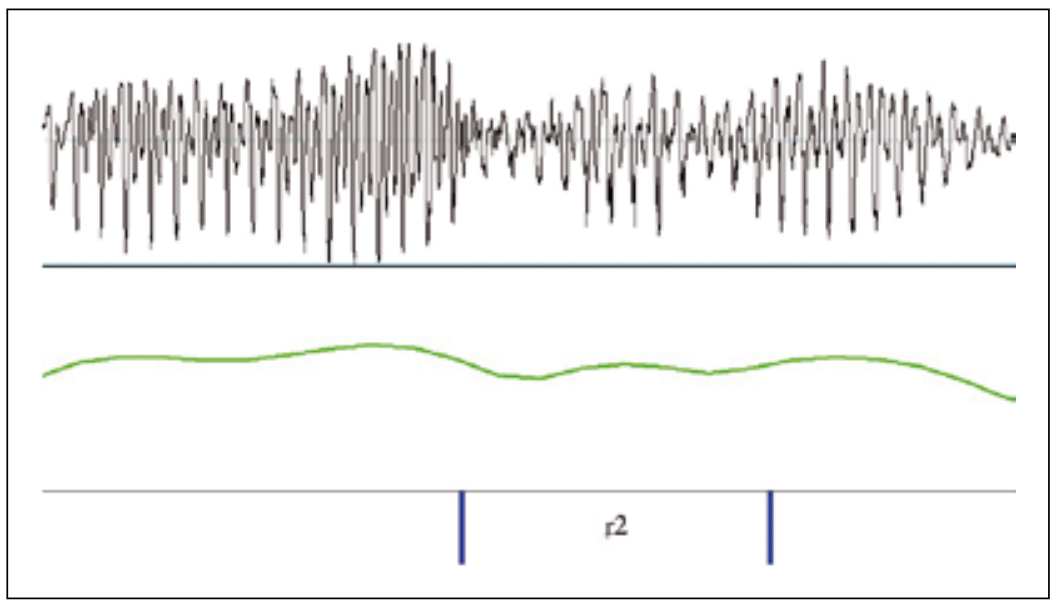

16. irudia. [r̦ 2] alofono hurbilkariaren energiaren ibilbidea (Atxondo, A taldeko neska, korrika).

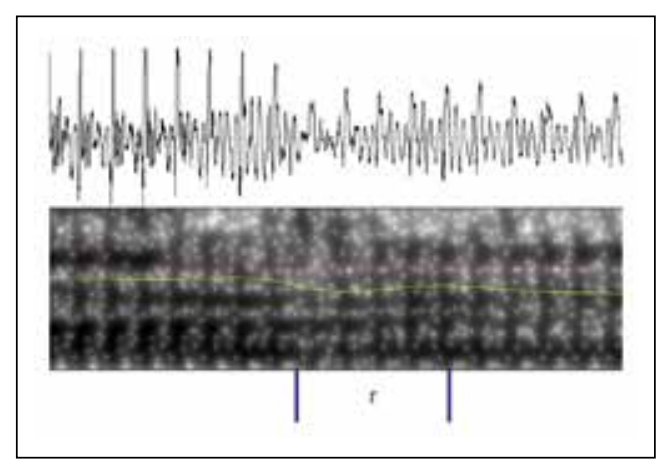

17. irudia. [ṛ] . alofono hurbilkaria (Iurreta, A taldeko mutila, irugarrenien).

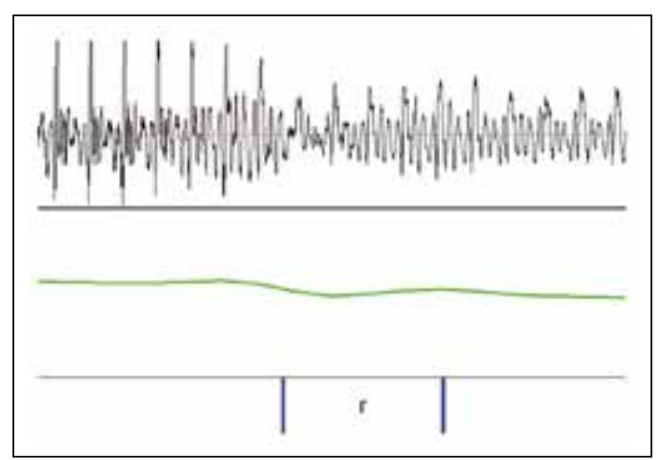

18. irudia. [r] . alofono hurbilkariaren energiaren ibilbidea (Iurreta, A taldeko mutila, irugarrenien). 
4. taulan alofono bakoitzaren kopuruak eta ehunekoak erakusten ditugu erabileraren arabera ordenatuta (19. irudiko grafikoa).

4. taula. Dardarkari apikariaren alofonoen kopuruak eta ehunekoak.

\begin{tabular}{|c|c|c|}
\hline Alofonoa & Kopurua & Ehunekoa \\
\hline$[\mathrm{r} 2]$ & 164 & 50,00 \\
\hline$[\widetilde{\mathrm{r}}]$ & 89 & 27,13 \\
\hline$[\widetilde{\mathrm{r}}]$ & 35 & 10,67 \\
\hline$[\mathrm{r} 3]$ & 28 & 8,54 \\
\hline$[\mathrm{r}]$ & 6 & 1,83 \\
\hline$[\mathrm{r} 2]$ & 5 & 1,52 \\
\hline$[\mathrm{r} 4]$ & 1 & 0,30 \\
\hline
\end{tabular}

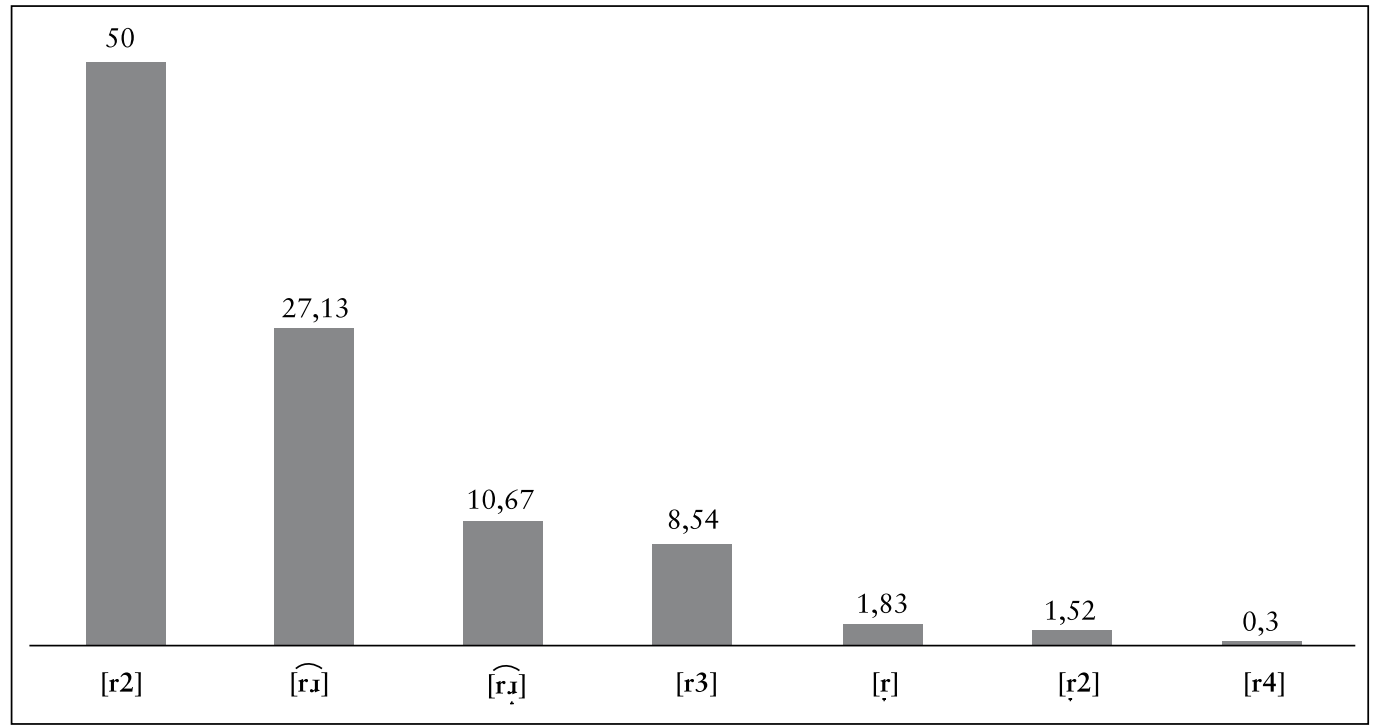

19. irudia. Dardarkari apikariaren alofonoen kopuruak eta ehunekoak.

Alofonoen ezaugarri akustikoak aztertzeko aukeratu ditugun indizeak iraupena eta energia izan dira.

Alofonoen iraupen osoari dagokionez, hertsigune bakarra daukatenak dira laburre-

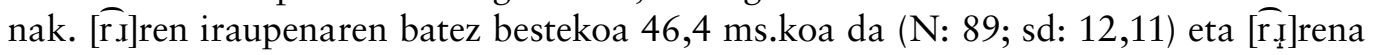
46,85 ms.koa (N: 35; sd: 14,37); aldea ez da estatistikoki esanguratsua. Jarraian [rir] eta [ri 2] kokatzen dira, lehenaren batez bestekoa 60 ms.koa da (N: 6; sd: 17,89) eta bigarrenarena 61,6 ms.koa (N: 5; sd: 7,3), aldea ez da estatistikoki esanguratsua.

Luzeenak hertsigune bi, hiru eta lau dauzkatenak dira. [r2] ren batez bestekoa 72,23 ms.koa da (N : 164, sd: 10,81) eta [r3]rena 97,5 (N: 28, sd: 10,28); aldea estatistikoki esanguratsua da $(\mathrm{t}=($ a.m.: 190$)-11,514 ; \mathrm{p}=0,000)$; hau da zenbat eta hertsigune 
gehiago eduki orduan luzeagoa da kontsonantea. Lau hertsiguneko adibide bakarra daukagun arren, berorren iraupena 131 ms.koa da.

[r2]ren kasuan lehen hertsigunea luzeagoa da 19,52 ms.koa (sd: 3,93) bigarrena baino, azken honen batez bestekoa 16,51 ms.koa da (sd 3,89); aldea estatistikoki esanguratsua $\mathrm{da}(\mathrm{t}=(\mathrm{a} . \mathrm{m} .:$ 326) 6,972; $\mathrm{p}=0,000)$. Bokal uneen iraupenei dagokienez, lehen bokal unearen batez bestekoa 19,30 ms.koa da (sd.: 3,81) eta bigarrenarena 16,88 ms.koa (sd: 6,51); bertan agertzen den aldea estatistikoki esanguratsua da $(t=(a . m .: ~ 326) 4,114$; $\mathrm{p}=0,000)$. Beraz une bakoitzaren iraupenaren batez bestekoak kontuan hartuta, esan dezakegu luzeena lehen hertsigunea dela, gero lehen bokal unea, gero azken bokal unea eta laburrena bigarren hertsigunea dela (20. irudiko grafikoa).

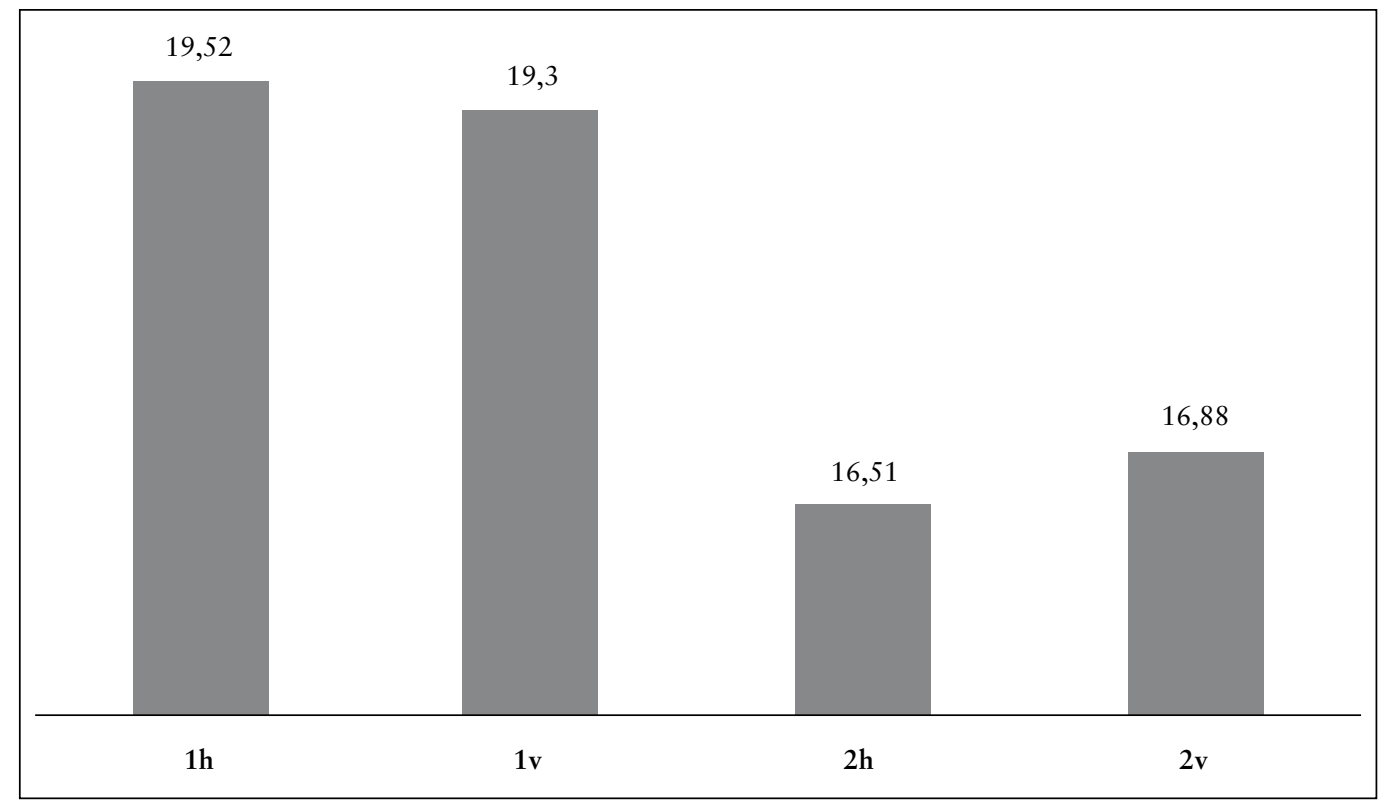

20. irudia. [r2] alofonoaren gune bakoitzaren iraupenaren batez bestekoak.

[r3]ren hertsiguneen eta bokal uneen iraupenaren batez bestekoak 5. taulan erakusten dira. Hertsiguneen arteko aldeak oso txikiak dira eta ez dira estatistikoki esanguratsuak; bokal uneei dagokienez, ostera, 3. bokal gunearen eta beste bien arteko aldea bada estatistikoki esanguratsua ANOVA post hoc tukeyren probaren arabera.

5. taula. [r3] alofonoaren gune bakoitzaren iraupenaren batez bestekoak eta desbiderapenak.

\begin{tabular}{|l|c|c|c|c|}
\hline & \multicolumn{2}{|c|}{ Hertsiguneak } & \multicolumn{2}{c|}{ Bokal uneak } \\
\hline & $\overline{\mathbf{x}}$ & sd & $\overline{\mathbf{x}}$ & sd \\
\hline $\mathbf{1}$ & 17,537 & 3,426 & 17,786 & 3,403 \\
\hline $\mathbf{2}$ & 17,321 & 3,067 & 17,464 & 3,179 \\
\hline $\mathbf{3}$ & 15,178 & 6,401 & 12,214 & 4,724 \\
\hline
\end{tabular}


Energia osoaren batez bestekoari dagokionez, hertsigune bakarrekoen kasuan 73,856 db.koa da (sd: 4,661), hertsigune bi edo gehiago direnean batez bestekoa 74,457 db.koa da (sd: 3,885) eta hertsigune bakoen kasuan 74,129 db.koa (sd.: 3,050); euren arteko aldeak ez dira estatistikoki esanguratsuak.

Hertsigune bakarrekoen kasuan energiaren aldea neurtu dugu soinuaren hasieratik beherengo puntura (h-e) eta honetatik soinuaren amaierara artekoa (e-a). 6. taulan aldeen ehunekoen batez bestekoak eta desbiderapenak erakusten dira.

6. taula. Hertsigune bakarreko alofonoen energiaren batez bestekoak eta desbiderapenak.

\begin{tabular}{|c|c|c|c|c|} 
& \multicolumn{2}{|c|}{ h-e } & \multicolumn{2}{c|}{ e-a } \\
\hline$[\widehat{[r}]$ & $\overline{\mathbf{x}}]$ & sd & $\overline{\mathbf{x}}$ & sd \\
\hline$[\widehat{[\mathrm{r}}]$ & 4,278 & 2,697 & 5,235 & 3,179 \\
\hline
\end{tabular}

Beherengo puntutik amaierara artean alofono bietan dagoen aldea estatistikoki esanguratsua da $(\mathrm{t}=($ a.m.: 122$)-5,563 ; \mathrm{p}=0,000)$.

\subsection{Alofonoen hedadura}

Alofonoen hedadura aztertzeko hiru multzo nagusi egin ditugu; batean hertsigune bitik gora dauzkatenak (h2) aztertu ditugu, beste batean hertsigune bakarra daukatenak zaratarekin eta zarata barik (h1) eta beste batean formakinak soinu osoan zehar dauzkatenak (h0).

Era berean, alofonoen erabileraren hedadurari eragin diezaioketen hiru eratako eragileak hartuko ditugu kontuan; linguistikoak, geografikoak eta sozialak. Eragile linguistikoetan hiru aztertu ditugu, dardarkariaren aurreko silaban agertzen diren kontsonantea eta bokala nahiz dardarkaria gauzatzen den talde prosodikoaren abiada.

Dardarkariaren aurreko silabaren hasiera hutsa izan daiteke (C0) edo kontsonante bat egon daiteke; agertu zaizkigun kontsonanteak talde nagusi bitan sailkatu ditugu: aurreko kontsonanteak (C1) hau da, ezpainetatik albeoloetara egiten direnak eta atzeko kontsonanteak (C2), talde honetan albeoloetatik atzera egiten diren guztiak kokatzen dira. 7. taulan alofonoen kopuruak ematen ditugu aurreko kontsonante moten arabera. Bertan agertzen diren aldeak ez dira estatistikoki esanguratsuak. 
7. taula. Alofonoen kopuruak eta ehunekoak aurreko silabaren kontsonante motaren edo kontsonante ezaren arabera.

\begin{tabular}{|l|c|c|c|c|c|c|c|c|}
\hline & \multicolumn{2}{|c|}{ C0 } & \multicolumn{2}{c|}{ C1 } & \multicolumn{2}{c|}{ C2 } & \multicolumn{2}{c|}{ Guztira } \\
\hline & kop & $\%$ & kop & $\%$ & kop & $\%$ & kop & $\%$ \\
\hline h2 & 94 & 48,70 & 33 & 17,10 & 66 & 34,20 & 193 & 100 \\
\hline h1 & 49 & 39,52 & 29 & 23,39 & 46 & 37,10 & 124 & 100 \\
\hline h0 & 4 & 36,36 & 2 & 18,18 & 5 & 45,45 & 11 & 100 \\
\hline
\end{tabular}

Aurreko silabaren bokalaren eragina aztertzeko tasun bi erabiliko ditugu, bokala aurrekoa edo atzekoa den eta bokala goikoa den edo ez (+aurrekoak: [i] eta [e] dira eta +goikoak: [o] eta [u]). 8. taulan dardarkariaren alofono bakoitzaren kopuruak eta ehunekoak ematen ditugu \pm aurrekoa bokalen arabera. Bertan agertzen diren aldeak ez dira estatistikoki esanguratsuak.

8. taula. Alofonoen kopuruak eta ehunekoak aurreko bokalen \pm aurrekoa tasunaren arabera.

\begin{tabular}{|l|c|c|c|c|c|c|}
\hline & \multicolumn{2}{|c|}{+ Aurrekoa } & \multicolumn{2}{c|}{ - Aurrekoa } & \multicolumn{2}{c|}{ Guztira } \\
\hline & kop & $\%$ & kop & $\%$ & kop & $\%$ \\
\hline h2 & 17 & 8,81 & 176 & 91,19 & 193 & 100 \\
\hline h1 & 19 & 15,32 & 105 & 84,68 & 124 & 100 \\
\hline h0 & 1 & 9,09 & 10 & 90,91 & 11 & 100 \\
\hline
\end{tabular}

9. taulan dardarkariaren alofonoen kopuruak eta ehunekoak ematen ditugu \pm goikoa bokalen arabera, bertan agertzen den aldea ez da estatistikoki esanguratsua.

9. taula. Alofonoen kopuruak eta ehunekoak aurreko bokalen \pm goikoa tasunaren arabera.

\begin{tabular}{|l|c|c|c|c|c|c|}
\hline & \multicolumn{2}{|c|}{+ Goikoa } & \multicolumn{2}{c|}{ - Goikoa } & \multicolumn{2}{c|}{ Guztira } \\
\hline & kop & $\%$ & kop & $\%$ & kop & $\%$ \\
\hline h2 & 21 & 10,88 & 172 & 89,12 & 193 & 100 \\
\hline h1 & 20 & 16,13 & 104 & 83,87 & 124 & 100 \\
\hline h0 & 2 & 18,18 & 9 & 81,82 & 11 & 100 \\
\hline
\end{tabular}

Azkenik, alofono bakoitza agertzen deneko talde prosodikoen abiadaren arabera aztertu ditugu; 10. taulan alofono bakoitza agertzen deneko talde prosodikoen abiadaren batez bestekoak eta desbiderapenak agertzen dira. ANOVA proba estatistikoaren arabera aldea estatistikoki esanguratsua da $(\mathrm{F}=(\mathrm{a} . \mathrm{m}: 2) 13,205 ; \mathrm{p}=0,000)$, Tukey post hoc probaren bidez h1 eta h2 alofonoen arteko aldea ez da estatistikoki esanguratsua, aldea esanguratsua da h2ri dagokionez. 
10. taula. Alofonoak kokatuta agertzen direneko talde prosodikoen abiadaren batez bestekoak eta desbiderapenak.

\begin{tabular}{|l|c|c|}
\hline & $\overline{\mathbf{x}}$ & sd \\
\hline h2 & 6,646 & 1,377 \\
\hline h1 & 7,480 & 1,586 \\
\hline h0 & 7,629 & 1,684 \\
\hline
\end{tabular}

Azterketa geografikoa egin ahal izateko Hegoaldeko A taldeko nesken datuak erabili ditugu. Multzokatze azterketa hierarkikoa erabili dugu Ward metodoaren bidez eta distantzia euklidear karratua erabilita. 21. irudiko dendrograman erakusten dira lortu diren multzo nagusi biak.

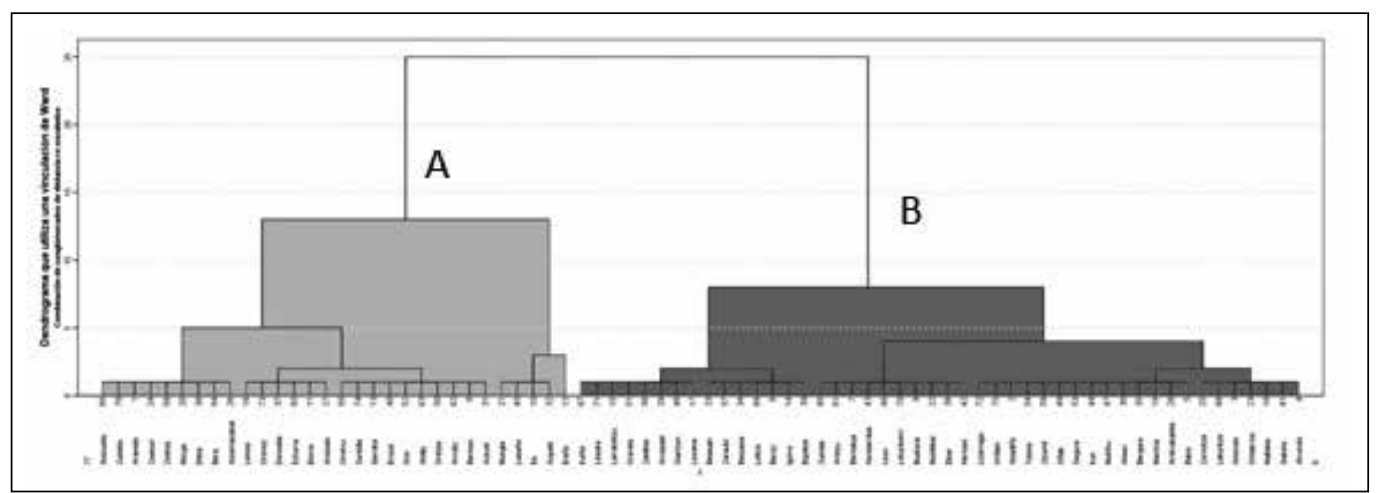

21. irudia. A taldeko nesken sailkapena dardarkari apikariaren alofonoen erabileraren arabera.

Multzo bakoitzeko informatzaileak probintziaka sailkatuta ematen ditugu 11. taulan; A multzoan 30 informatzaile kokatzen dira (\% 39,47) eta B multzoan 46 (\% 60,53).

11. taula. A taldeko nesken sailkapena talde bitan, dardarkari apikariaren alofonoen erabileraren arabera.

\begin{tabular}{|c|l|l|}
\hline Multzoa & Probintzia & \multicolumn{1}{c|}{ Informatzaileak } \\
& Araba & Aramaio \\
\cline { 2 - 3 } A & Bizkaia & Bermeo, Ea, Elorrio, Ereño, Gernika, Lemoa, Morga, Mungia eta Zeanuri \\
\cline { 2 - 3 } & Gipuzkoa & $\begin{array}{l}\text { Aizarnazabal, Andoain, Azkoitia, Azpeitia, Deba, Donostia, Errezil, Lasarte, } \\
\text { Ordizia, Orio, Urretxu eta Zestoa }\end{array}$ \\
\cline { 2 - 4 } & Nafarroa & Arruitz, Atallu, Bera, Goizueta, Oronoz, Ezkurra, Sunbilla eta Zubieta \\
\hline \multirow{4}{*}{ B } & Bizkaia & $\begin{array}{l}\text { Abadiño, Amoroto, Atxondo, Bakio, Berriatua, Berriz, Busturia, Igorre, } \\
\text { Larrabetzu, Lezama, Mallabia, Markina, Munitibar, Ondarroa eta Zornotza }\end{array}$ \\
\cline { 2 - 4 } & Gipuzkoa & $\begin{array}{l}\text { Aretxabaleta, Arrasate, Ataun, Beasain, Beizama, Bergara, Eibar, Elgoibar, } \\
\text { Gabiria, Hernani, Hondarribia, Irun, Lezo, Mutriku, Oiartzun, Oñati, Orereta, } \\
\text { Segura, Tolosa, Zaldibia, Zarautz, Zizurkil eta Zumaia }\end{array}$ \\
\hline & Nafarroa & Arbizu, Irurita, Lakuntza, Leitza, Lekunberri, Lesaka, Lizarraga eta Urdiain \\
\hline
\end{tabular}


22. irudiko mapan multzo bakoitzaren hedadura geografikoa erakusten da, bertan ikusten den moduan badaude zonalde konpaktu batzuk, hala nola Bizkaiko Lea-Artibaik eta Durangaldeak osatzen dutena, Gipuzkoako mendebaldean, ekialdean, Urolan eta Goierrin eta Nafarroako Sakanan eta Malerrekan nahiko zonalde homogeneoak agertzen dira.

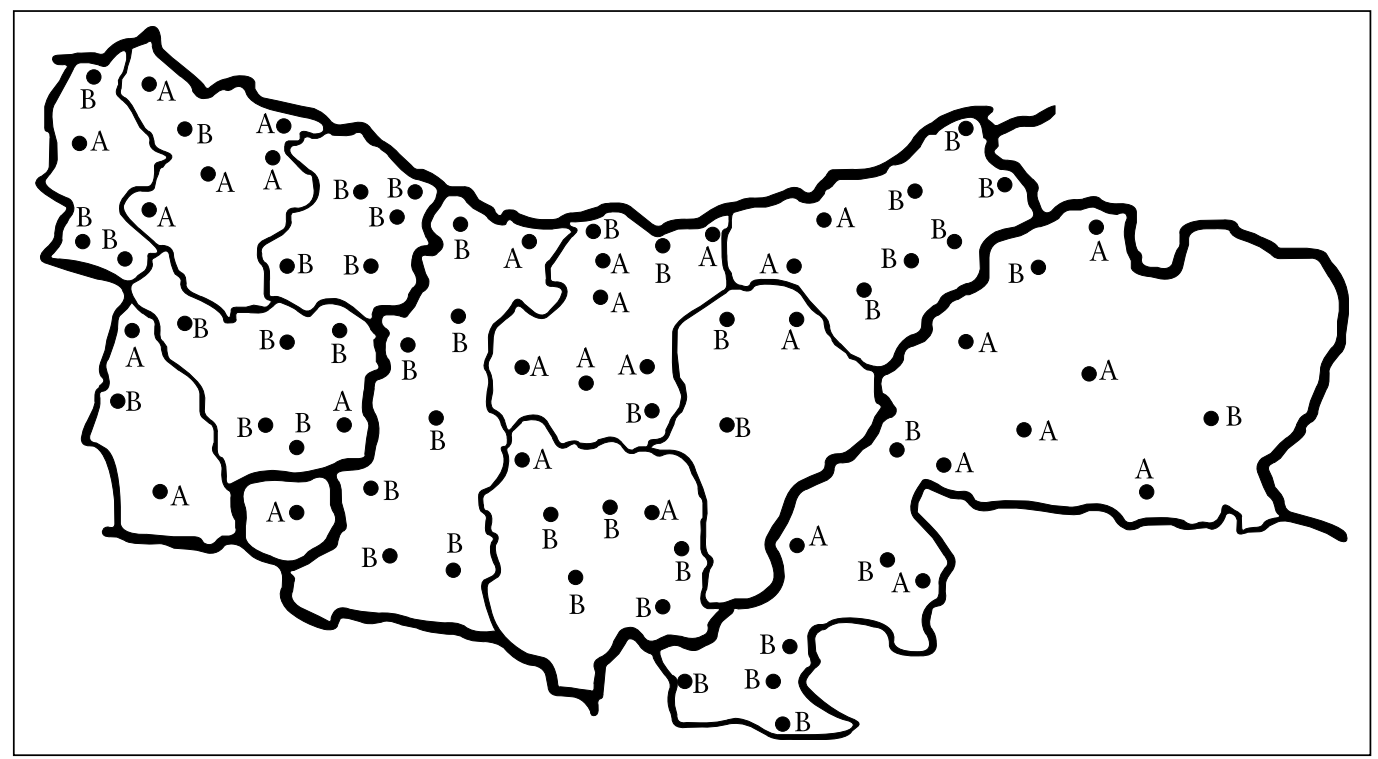

22. irudia. A taldeko nesken sailkapenaren hedadura geografikoa, dardarkari apikariaren alofonoen erabileraren arabera.

Alofonoen agerpenak informatzaileen generoaren arabera aztertzen baditugu 12 . taulako kopuruak eta ehunekoak lortzen dira talde bakoitzeko; kontuan hartu behar da informatzaile talde bakoitzeko kopurua ez dela homogeneoa. Edozelan ere, bertan agertzen diren aldeak estatistikoki esanguratsuak dira khi karratu estatistikoaren arabera $(\chi 2=($ a.m.: 2) 23,83; $\mathrm{p}=0,000)$.

12. taula. Alofonoen kopuruak eta ehunekoak informatzaileen generoaren arabera.

\begin{tabular}{|l|c|c|c|c|}
\hline \multicolumn{3}{|c|}{ Neskak } & \multicolumn{2}{c|}{ Mutilak } \\
\hline h2 & kop & $\%$ & kop & $\%$ \\
\hline h1 & 136 & 64,15 & 18 & 32,14 \\
\hline h0 & 72 & 33,96 & 32 & 57,14 \\
\hline Guztira & 4 & 1,89 & 6 & 10,71 \\
\hline
\end{tabular}

Gauza bera egiten badugu informatzaileen ama hizkuntzaren arabera 13. taulako kopuruak eta ehunekoak lortzen dira; kasu honetan bertan agertzen diren aldeak ez dira estatistikoki esanguratsuak. 
13. taula. Alofonoen kopuruak eta ehunekoak informatzaileen ama hizkuntzaren arabera.

\begin{tabular}{|l|c|c|c|c|}
\hline \multicolumn{2}{|c|}{ A } & \multicolumn{2}{c|}{ B } \\
\hline h2 & kop & $\%$ & kop & $\%$ \\
\hline h1 & 136 & 64,15 & 39 & 65,00 \\
\hline h0 & 72 & 33,96 & 20 & 33,33 \\
\hline Guztira & 4 & 1,89 & 1 & 1,67 \\
\hline
\end{tabular}

\subsection{Dardarkari ubularra}

Bokalen arteko dardarkari ubularrak 173 izan dira gure corpusean, hau da, dardarkari anizkun guztien \% 34,53. Artikulatorioki esaten izan da nahikoa dela ixte lasterraren errepikapena egitea (Oñederra, 2004), ubularraren kasuan ixtea aho-gingilean egiten dela adierazten du egile berak (Oñederra, 2004). Txillardegik (1980) eta Oñederrak (2004) ubularra frikaria izan daitekeela ere esaten dute eta ubularraren alofonotzat jotzen da. Beste hizkuntza batzuetan adierazi den moduan, aldakortasun fonetiko handia topatzen da honetan (Demolin, 2001; Hambye, 2005); gurean ere alofono bi baino gehiago topatzen dira.

Aurreko azpi-atalean egin dugun bezala, azpi-atal hau ere sekzio bitan banatuta emango dugu; lehen sekzioan alofonoen deskripzioekin batera indize akustikoen emaitzak emango ditugu, bigarrenean, arinago aipatu diren irizpideen arabera alofonoen hedadura aztertuko da.

\section{Alofonoen deskripzioak}

Ubularren tasun akustikoak aztertzeko ikusten dugun lehen ezaugarria da, apikarien aldean, sei edo zazpi hertsigune eta beste horrenbeste bokal une agertzen direla, 23. irudiko espektrograman ikusten den moduan, bertan dardarkarian zehar gertatzen diren formakinak ere ikusten dira.

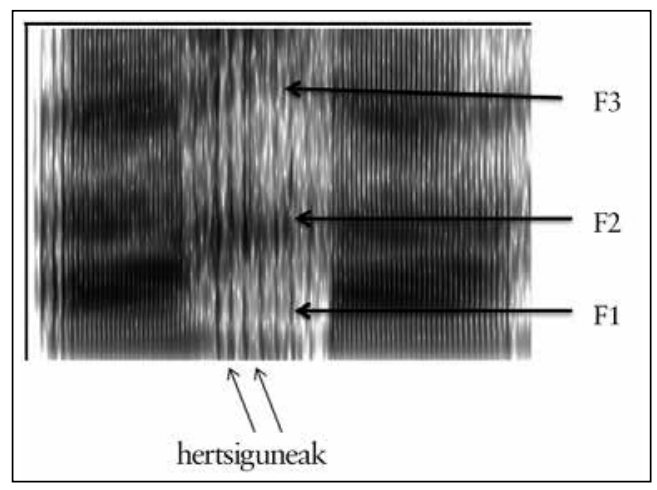

23. irudia. $[\mathrm{R}]$ ren hertsiguneak eta formakinak (Baigorri, A taldeko neska, arra).
Azpi atal honetan agertu zaizkigun alofonoen deskripzioa egitean, barietate handia dagoen arren, hiru multzo nagusi egin daitezke: dardarkari ubularrak (D1) (trill), frikari ubularrak (D2) eta bien ezaugarriak biltzen dituztenak (D3).

Lehenengoetan alofono bi agertu zaizkigu; batean, $[\mathrm{R}]$, hertsigune eta bokal une txikiak agertzen dira goitik behera (24. irudiko espektrograma). Energiari dagokionez, ikusten dugu hasierako beherakadaren ondoan, kontsonantearen erdiko 
aldean, energiak gora egiten duela bere ibilbidean amaieran berriro apaltzeko (25. irudiko espektrograma).

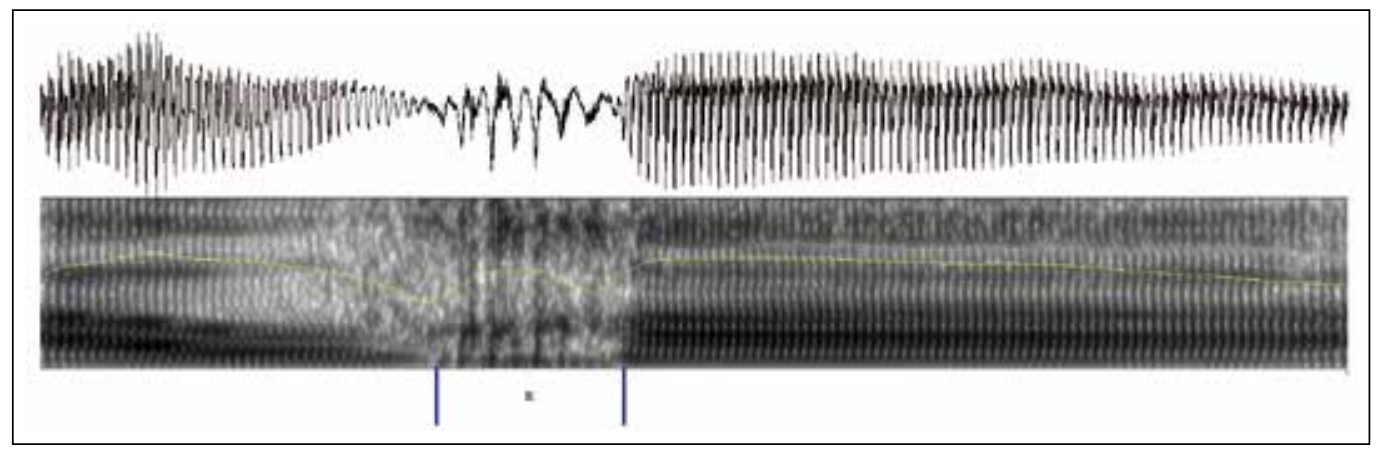

24. irudia. $[\mathrm{R}]$ alofono dardarkaria (Baigorri, A taldeko neska, aurra).

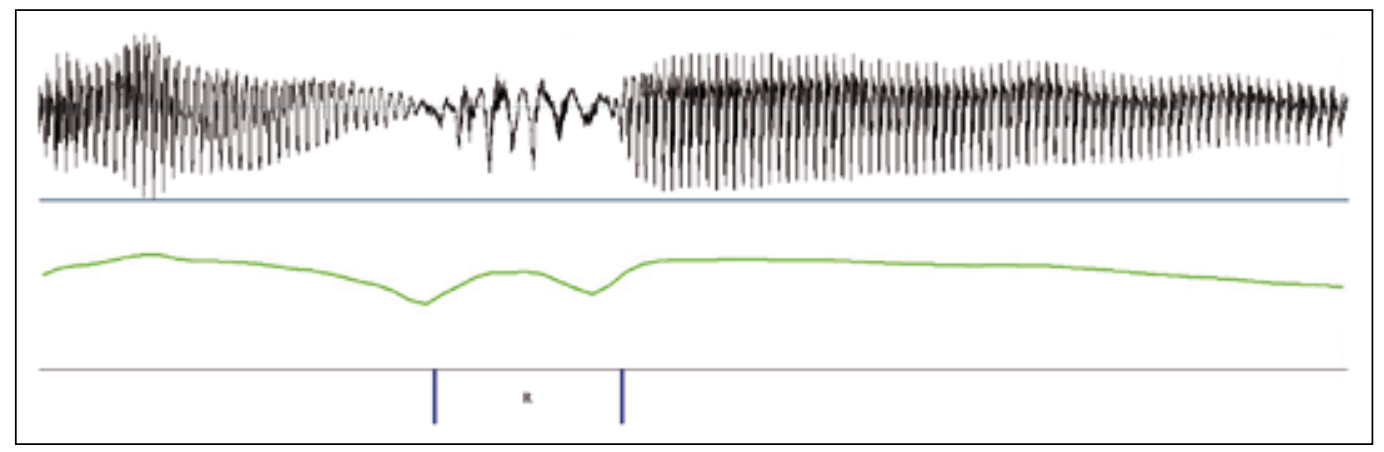

25. irudia. $[\mathrm{R}]$ alofono dardarkariaren energiaren ibilbidea (Baigorri, A taldeko neska, aurra).

Beste alofonoa [Rָ] dugu, hurbilkarietan gertatzen den bezala, hertsiguneez eta bokal uneez gain, aldameneko formakinak kontsonantean zehar ikus daitezke (26. irudiko espektrograma). Energiaren ibilbidea aztertuz gero, ikusten dugu energia apaldu egiten dela kontsonante osoan zehar (27. irudiko espektrograma).

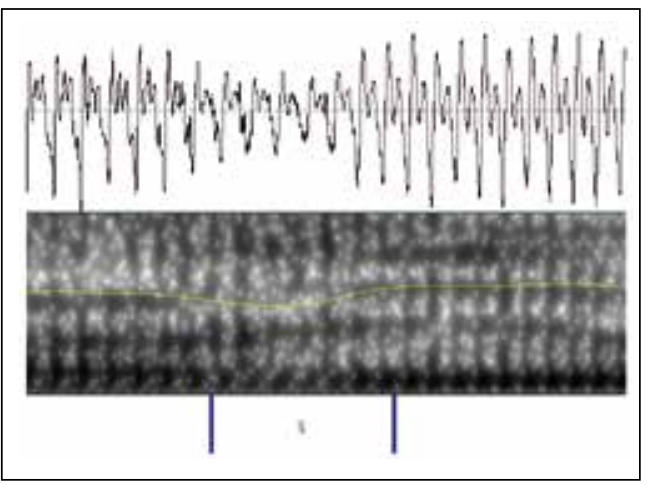

26. irudia. [R $]$ alofono dardarkari hurbilkaria (Barkoxe, A taldeko mutila, harri).

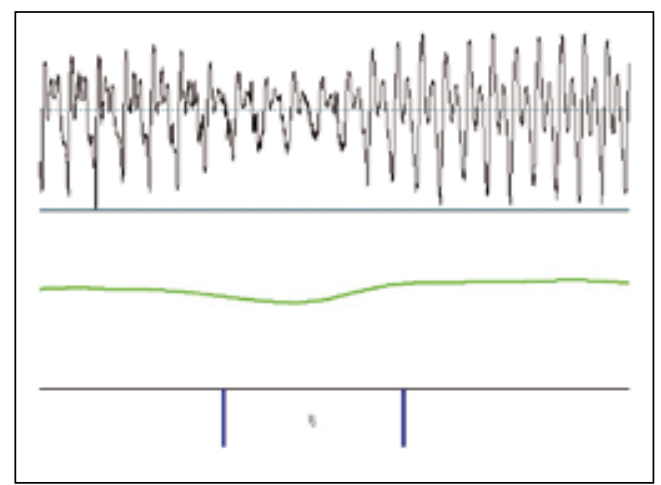

27. irudia. $[\mathrm{R}]$ alofono dardarkari hurbilkariaren energiaren ibilbidea (Barkoxe, A taldeko mutila, harri). 
Alofono frikarietan zarata agertzen da goitik behera eta hertsigune argirik ez da egoten. Hauetan hiru mota agertzen dira. [в] frikari ahostuna da (28. irudiko espektrograma), energiaren ibilbidean berau kontsonante osoan zehar apalduta agertzen dela ikus dezakegu 29. irudiko espektrograman.

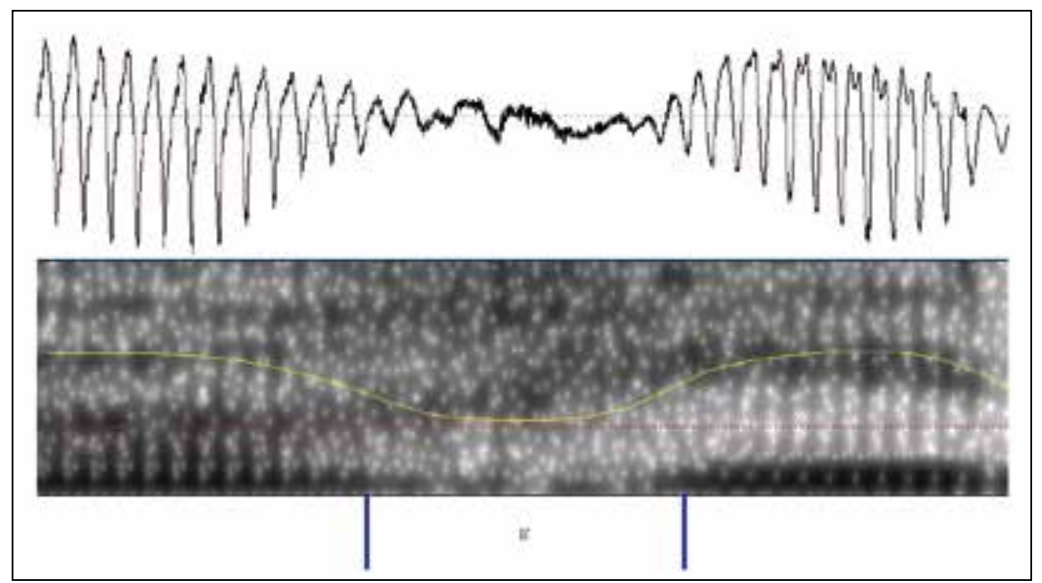

28. irudia. [в] alofono frikaria (Urdiñarbe, A taldeko neska, harrituik).

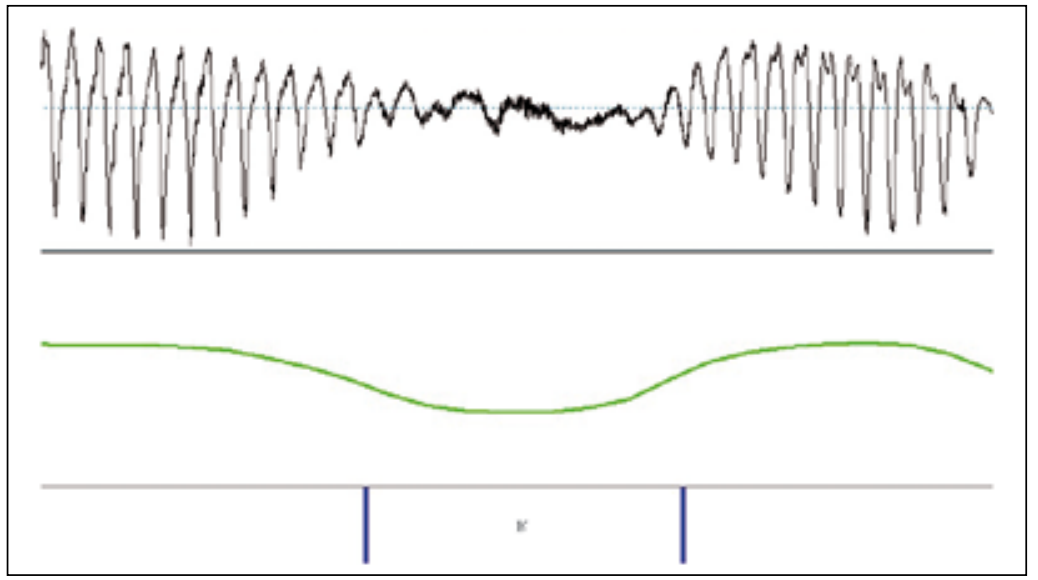

29. irudia. [в] alofono frikariaren energiaren ibilbidea (Urdiñarbe, A taldeko neska, harrituik). 
Kasu batzuetan, 30. irudiko espektrograman legez, aldameneko bokalen formakinak agertzen dira kontsonantean zehar, honelakoetan $[\underset{\mathrm{T}}{\mathrm{b}}]$ ikurra erabil daiteke; energiaren ibilbidean berau aldameneko bokaletan baino apalagoa dela ikus dezakegu; hala ere, [бㅜ]ren energiaren aldean beronena altuagoa da (31. irudiko espektrograma).

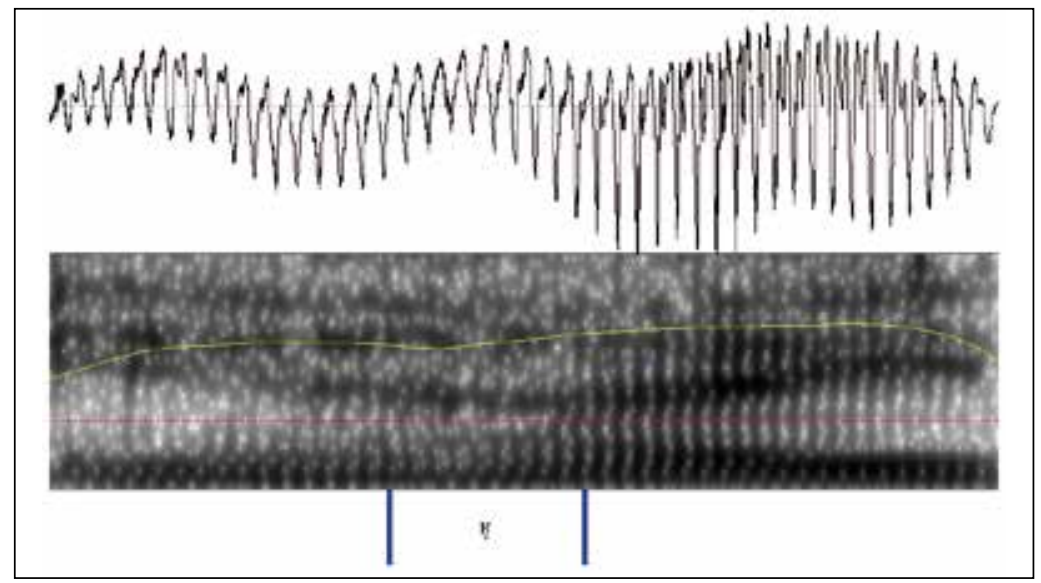

30. irudia. [ڤָ] alofono frikari hurbilkaria (Urdiñarbe, A taldeko neska, jarri).

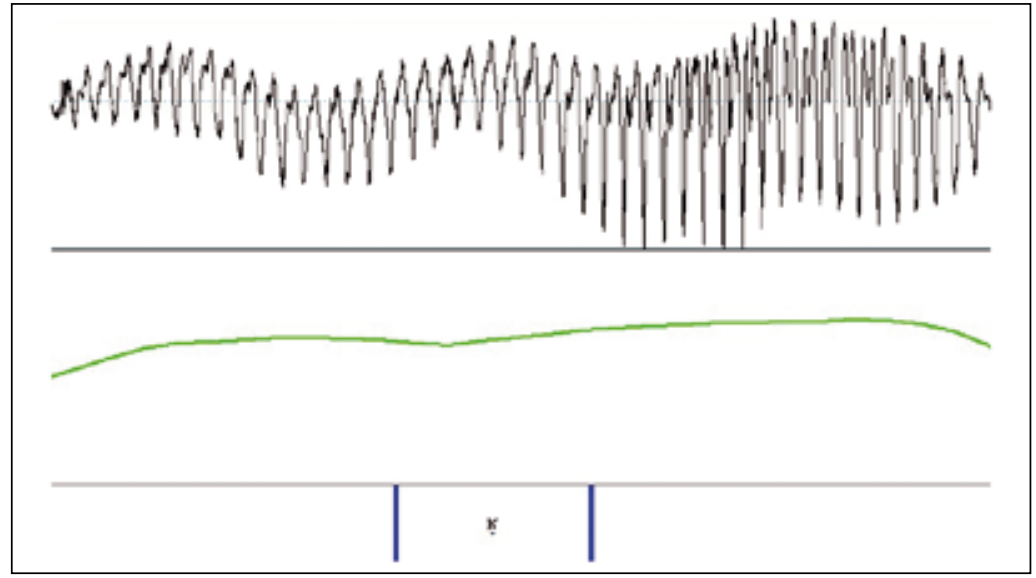

31. irudia. [ธָ] ] alofono frikari hurbilkariaren energiaren ibilbidea (Urdiñarbe, A taldeko neska, jarri).

Azkenik, frikaria ahoskabetu daiteke 32. irudiko espektrograman erakusten den legez, honelakoetan [ь ] ikurra erabil daiteke. Energiari erreparatuta (33. irudiko espektrograma), berau kontsonantean zehar oso apaltzen dela ikus dezakegu. 


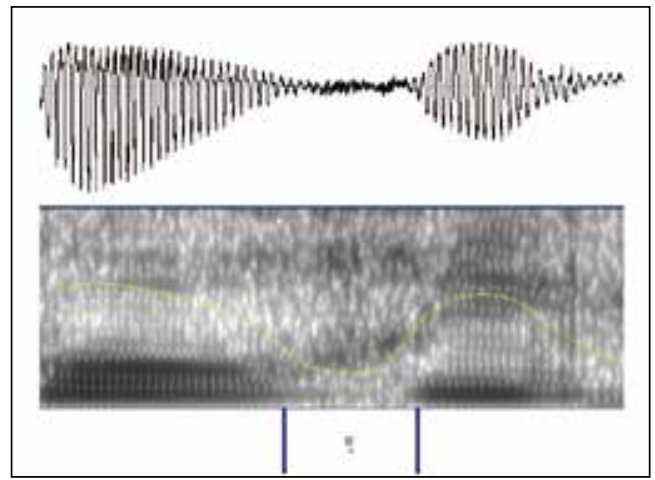

32. irudia. [ъ] alofono frikari hurbilkari ahoskabetua (Hazparne, A taldeko neska, korrika).

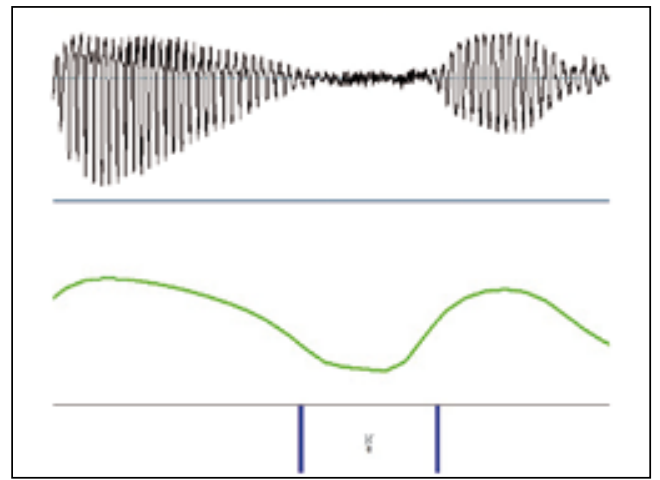

33. irudia. [ъ] alofono frikari hurbilkari ahoskabetuaren energiaren ibilbidea (Hazparne, A taldeko neska, korrika).

[ъ ] ikurra aukeratu dugu frikari ahoskabea adierazteko. Belgikako frantsesaren dardarkariak (Demolin, 2001) aztertzean, esate baterako, $[\chi]$ proposatu den arren, gure kasuan ahoskabetze ikurra erabiltzea nahiago izan dugu $[\chi]$ baino, izan ere, gure corpusean $[\chi] / x /$ fonemaren alofonotzat jo daiteke atzeko bokalekin batera agertzen denean.

34. irudiko espektroan ikusten den dardarkarian zati bi daude, lehen zatian hertsiguneak eta bokal guneak agertzen dira eta bigarrenean ez; gainera azken hau ahoskabea da, berau adierazteko $[\overline{\mathrm{R}}$ бo $]$ ikurra erabili dugu. Alofonoaren energiari dagokionez ere, zati bi bereiz daitezke, hasieran energiak gorantz egiten du [R]rekin gertatzen den bezala; gero bigarren zatian apaltzeko [в] ]rekin gertatzen den bezala (35. irudiko espektrograma).

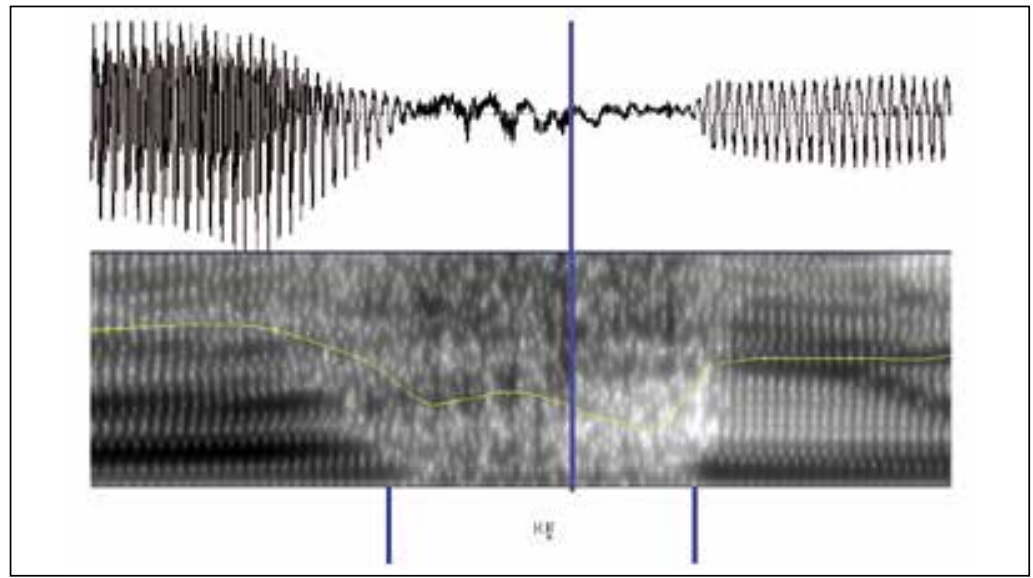

34. irudia. $\left[\widehat{\mathrm{Rg}_{\mathrm{r}}}\right]$ alofonoa (Hazparne, A taldeko neska, arri bat). 


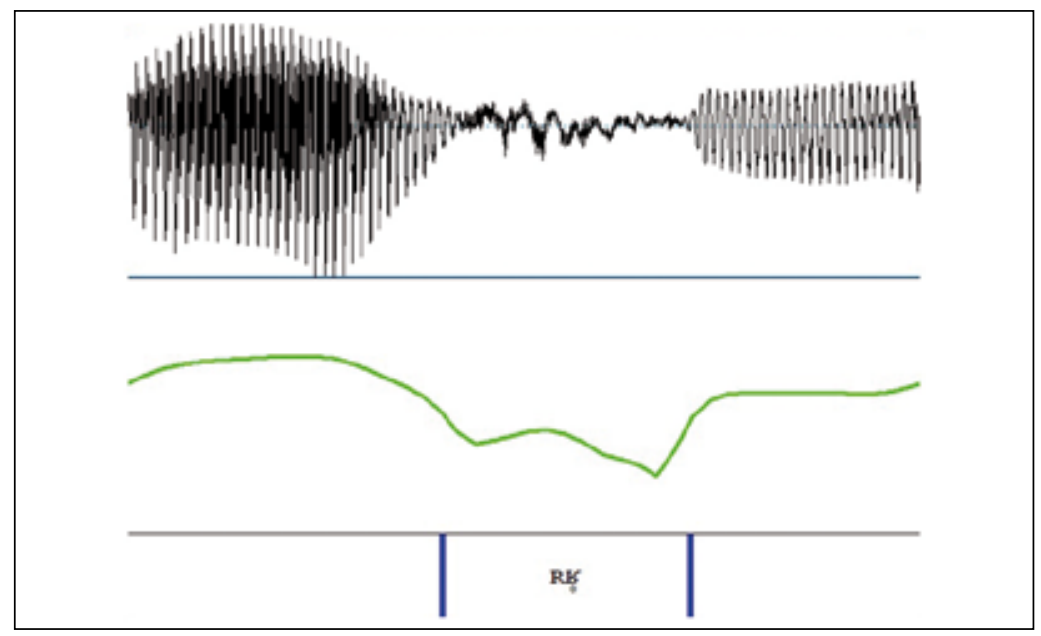

35. irudia. $[\widehat{\mathrm{R}} \mathrm{g}]$ alofonoaren energiaren ibilbidea (Hazparne, A taldeko neska, arri bat).

Ikusi ditugun dardarkari ubularraren alofonoen tasun akustikoak aztertzeko hiru multzo nagusiak banan ikusiko ditugu (dardarkari ubularrak D1, frikariak D2 eta bien artekoak D3). Aukeratu ditugun indize akustikoak iraupenari eta energiari dagozkienak dira. Iraupen osoari dagokionez, 14. taulan erakusten den moduan, D3 askozaz luzeagoa da beste biak baino; ANOVA estatistikoaren bidez aldeak aztertuta, esanguratsuak direla agertzen zaigu $(\mathrm{F}=(\mathrm{a} . \mathrm{m} .: 2) 17,743 ; \mathrm{p}=0.000)$, Tukey post hoc probaren arabera, D1 eta D2 moten arteko aldea ez da esanguratsua, bestearena, ostera, bai.

14. taula. Alofonoen iraupen osoaren batez bestekoak eta desbiderapenak.

\begin{tabular}{|l|c|c|c|} 
& $\mathbf{N}$ & $\overline{\mathbf{x}}$ & sd \\
\hline D1 & 53 & 82,509 & 19,341 \\
\hline D2 & 88 & 72,511 & 28,121 \\
\hline D3 & 32 & 102,5 & 20,91 \\
\hline
\end{tabular}

D3 motaren lehen zatia luzeagoa da bigarrena baino; beronen batez bestekoa 60,66 ms.koa da (sd.: 14,42) eta bigarren zatiarena 41,84 ms.koa (sd: 12,28).

Energia osoari dagokionez (15. taula), energiarik altuena D1ek dauka eta baxuena D2k. ANOVAren azterketak aldea estatistikoki esanguratsua dela ematen digu (F $=(\mathrm{a} . \mathrm{m} . \mathrm{s}$ 2) 5,215; $\mathrm{p}=0.006)$, Tukey post hoc probaren arabera, D1 eta D2 multzoen artean dagoen aldea da esanguratsua den bakarra. 
15. taula. Alofonoen energia osoaren batez bestekoak eta desbiderapenak.

\begin{tabular}{|l|c|c|c|} 
& $\mathbf{N}$ & $\overline{\mathbf{x}}$ & sd \\
\hline D1 & 53 & 70,751 & 6,518 \\
\hline D2 & 88 & 67,296 & 6,257 \\
\hline D3 & 32 & 68,424 & 5,181 \\
\hline
\end{tabular}

Energiak kontsonantean zehar gorabeherak edukitzen ditu; gorabehera horiek alofono motak baldintzatuak diren jakiteko energia hiru unetan neurtu dugu; kontsonantearen hasieran, amaieran eta erdialdean, azken honetan D2 eta D3 alofonoen kasuan sarritan bat egiten du energiaren beherengo puntuarekin. 16. taulan alofono multzo bakoitzaren energiaren batez bestekoak eta desbiderapenak ematen dira une bakoitzeko. Bertan ikusten den bezala, kontsonantearen hasieran ez dago alde handirik; dauden aldeak ez dira estatistikoki esanguratsuak. Erdian agertzen den aldea handiena da, D1 motakoek energia handiagoa daukate besteek baino, alde hau estatistikoki esanguratsua da ANOVAren arabera ( $\mathrm{F}=(\mathrm{a} . \mathrm{m}: 2) 16,554 ; \mathrm{p}=0,000)$ Tukey post hoc probaren arabera, dardarkari ubularra (D1) da besteetatik aldentzen dena.

16. taula. Alofonoen energiaren batez bestekoak eta desbiderapenak soinuaren hasieran, erdian eta amaieran.

\begin{tabular}{|l|c|c|c|c|c|c|} 
& \multicolumn{2}{|c|}{ D1 } & \multicolumn{2}{c|}{ D2 } & \multicolumn{2}{c|}{ D3 } \\
& $\overline{\mathbf{x}}$ & sd & $\overline{\mathbf{x}}$ & sd & $\overline{\mathbf{x}}$ & sd \\
\hline Hasieran & 70,452 & 6,008 & $69,32,7$ & 6,5463 & 71,526 & 4,942 \\
\hline Erdian & 70,781 & $7,84,3$ & 63,816 & 7,316 & 63,004 & 7,872 \\
\hline Amaieran & 71,289 & $5,36,9$ & 71,602 & 5,254 & 71,374 & 3,923 \\
\hline
\end{tabular}

Azkenik, bidenabar besterik ez bada ere, ohar txiki bat egin nahi izan dugu dardarkari biak batera erabiltzearen gainean. Txillardegiren ohar batean (1980) esaten da ezen, apikaria eta ubularra ezin ager daitezkeela ingurune berean. Gure Baigorriko informatzaile gaztearen 36. eta 37. irudietako espektrogrametan agertzen den bezala hobikaria eta ubularra ingurune berean agertzen dira.

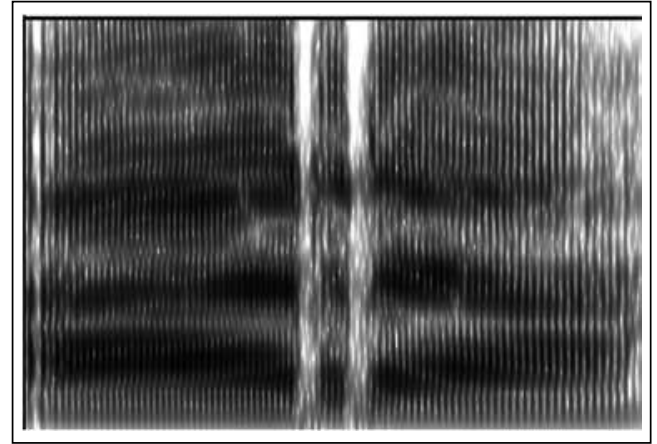

36. irudia. Baigorriko [r]a «a__a» ingurunean.

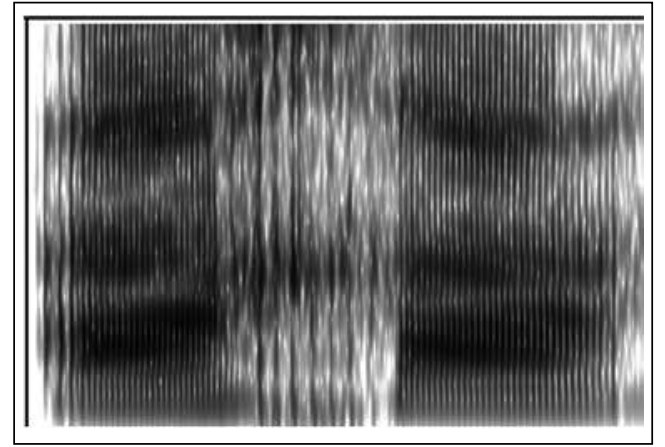

37. irudia. a Baigorriko $[\mathrm{R}] \mathrm{a}$ «a__a» ingurunean. 
Gertakari hau azal daiteke dardarkari anizkun albeolarra ubular bihurtu delako eta gero bakunaren artikulazioa indartu delako ondoko eskemaren arabera:

(a) $[\mathrm{r}]>[\mathrm{R}]$

(b) $[\mathrm{r}]>[\mathrm{r}]$

Jarraian informatzaile honen dardarkari bien iraupenak, energiak eta F1, F2 eta F3 formakinak aztertuko ditugu. Datuak a___a ingurunean jaso dira. 17. taulan izari bakoitzaren batez bestekoak eta desbiderapenak agertzen dira, F eta p estatistikoekin batera.

17. taula. Alofono bien prametroen batez bestekoak, desbiderapenak, F estatistikoaren emaitzak eta esanguratasun maila.

\begin{tabular}{|l|c|c|r|r|r|r|}
\hline & \multicolumn{2}{|c|}{$[\mathbf{r}]$} & \multicolumn{2}{c|}{ [R] } & \multicolumn{2}{c|}{ D3 } \\
\hline Iraupena & $\overline{\mathbf{x}}$ & $\mathbf{s d}$ & $\overline{\mathbf{x}}$ & $\mathrm{sd}$ & $\overline{\mathbf{x}}$ & sd \\
\hline Energia & 63,33 & 10,57 & 144,4 & 15,22 & 177,680 & 0,001 \\
\hline F1 & 83,54 & 1,54 & 78,96 & 1,22 & 52,074 & 0,001 \\
\hline F2 & 614,67 & 23,97 & 849,20 & 97,81 & 48,831 & 0,001 \\
\hline F3 & 1763,33 & 39,66 & 1592 & 60,33 & 52,132 & 0,001 \\
\hline
\end{tabular}

17. taulan argi agertzen den moduan, izari guztietan gertatzen diren aldeak estatistikoki esanguratsuak dira. Iraupenari dagokionez, ubularra luzeagoa da albeolarra baino. Energiari dagokionez, albeolarrarena handiagoa da ubularrarena baino. Albeolarraren F1 baxuagoa da, F2 altuagoa eta F3 baxuagoa.

\subsection{Alofonoen hedadura}

Alofonoen erabileraren hedadura aztertzeko, apikariarekin egin dugun moduan, hiru eratako eragileak hartuko ditugu kontuan; linguistikoak, geografikoak eta sozialak.

Alofonoen erabilerari eragin diezaioketen faktoreetan hiru aztertu ditugu, dardarkariaren aurreko silaban agertzen diren kontsonantea eta bokala eta dardarkaria gauzatzen deneko talde prosodikoaren abiada.

Dardarkariaren aurreko silabaren hasiera hutsa izan daiteke (C0) edo kontsonante bat egon daiteke; agertu zaizkigun kontsonanteak talde nagusi bitan sailkatu ditugu: aurreko kontsonanteak (C1) hau da, ezpainetatik albeoloetara egiten direnak eta atzeko kontsonanteak (C2), talde honetan albeoloetatik atzera egiten diren guztiak kokatzen dira. 18. taulan fonemen kopuruak ematen ditugu aurreko kontsonante moten arabera. D1 multzoko alofono gehienak agertzen dira aurreko silaban kontsonanterik ez dagoenean, gauza bera gertatzen da D3 multzoko alofonoarekin; D2 alofono frikariak, ostera, gehiago agertzen dira atzeko kontsonanteekin. Aldea khi karratu estatistikoaren arabera esanguratsua da $(\chi 2=($ a.m.: 4$) 9,822 ; \mathrm{p}=0,044)$. 
18. taula. Alofonoen kopuruak eta ehunekoak aurreko silabaren kontsonante motaren edo kontsonante ezaren arabera.

\begin{tabular}{|l|c|c|c|c|c|c|c|c|}
\hline \multicolumn{2}{|c|}{ C0 } & \multicolumn{2}{c|}{ C1 } & \multicolumn{2}{c|}{ C2 } & \multicolumn{2}{c|}{ Guztira } \\
& kop & $\%$ & kop & $\%$ & kop & $\%$ & kop & $\%$ \\
\hline D1 & 28 & 52,83 & 10 & 18,87 & 15 & 28,30 & 53 & 30,64 \\
\hline D2 & 25 & 28,41 & 23 & 26,14 & 40 & 45,45 & 88 & 50,87 \\
\hline D3 & 15 & 46,88 & 8 & 25,00 & 9 & 28,13 & 32 & 18,50 \\
\hline
\end{tabular}

Aurreko silabaren bokalaren eragina aztertzeko tasun bi erabiliko ditugu, bokala aurrekoa edo atzekoa den eta bokala goikoa den edo ez. 19. taulan dardarkariaren alofono bakoitzaren kopuruak eta ehunekoak ematen ditugu \pm aurreko bokalen arabera. Bertan agertzen diren aldeak ez dira estatistikoki esanguratsuak.

19. taula. Alofonoen kopuruak eta ehunekoak aurreko bokalen \pm aurrekoa tasunaren arabera.

\begin{tabular}{|l|c|c|c|c|c|c|}
\hline & \multicolumn{2}{|c|}{+ Aurrekoa } & \multicolumn{2}{c|}{ - Aurrekoa } & \multicolumn{2}{c|}{ Guztira } \\
& kop & $\%$ & kop & $\%$ & kop & $\%$ \\
\hline D1 & 12 & 22,64 & 41 & 77,36 & 53 & 30,64 \\
\hline D2 & 12 & 13,64 & 76 & 86,36 & 88 & 50,87 \\
\hline D3 & 4 & 12,50 & 28 & 87,50 & 32 & 18,50 \\
\hline
\end{tabular}

20. taulan dardarkariaren alofonoen kopuruak eta ehunekoak ematen ditugu \pm goiko bokalen arabera, bertan agertzen den aldea ez da estatistikoki esanguratsua.

20. taula. Alofonoen kopuruak eta ehunekoak aurreko bokalen \pm goikoa tasunaren arabera.

\begin{tabular}{|l|c|c|c|c|c|c|}
\hline & \multicolumn{2}{|c|}{+ Goikoa } & \multicolumn{2}{c|}{ - Goikoa } & \multicolumn{2}{c|}{ Guztira } \\
\hline kop & $\%$ & kop & $\%$ & kop & $\%$ \\
\hline D1 & 13 & 24,53 & 40 & 75,47 & 53 & 30,64 \\
\hline D2 & 18 & 20,45 & 70 & 79,55 & 88 & 50,87 \\
\hline D3 & 2 & 6,25 & 30 & 93,75 & 32 & 18,50 \\
\hline
\end{tabular}

Azkenik, alofono bakoitza agertzen deneko talde prosodikoen abiadaren arabera aztertu dugu; 21. taulan alofono bakoitza agertzen deneko talde prosodikoen abiadaren batez bestekoak eta desbiderapenak agertzen dira. ANOVA proba estatistikoaren arabera aldea estatistikoki esanguratsua da $(F=(a \cdot m: 2) 3,536 ; p=0,031)$, Tukey post hoc probaren bidez alofono multzo guztiek talde independenteak osatzen dituzte. 
21. taula. Alofonoak kokatuta agertzen direneko talde prosodikoen abiadaren batez bestekoak eta desbiderapenak.

\begin{tabular}{|c|c|c|}
\hline & $\overline{\mathbf{x}}$ & sd \\
\hline D1 & 5,392 & 1,237 \\
\hline D2 & 5,902 & 1,390 \\
\hline D3 & 5,307 & 1,400 \\
\hline
\end{tabular}

Azterketa geografikoa egin ahal izateko A taldeko nesken datuak erabili ditugu. Multzokatze azterketa hierarkikoa erabili dugu; apikariarekin egin dugun bezala, Ward metodoa eta distantzia euklidear karratua erabili dira. 38. irudiko dendrograman erakusten dira lortu diren multzo nagusi biak.

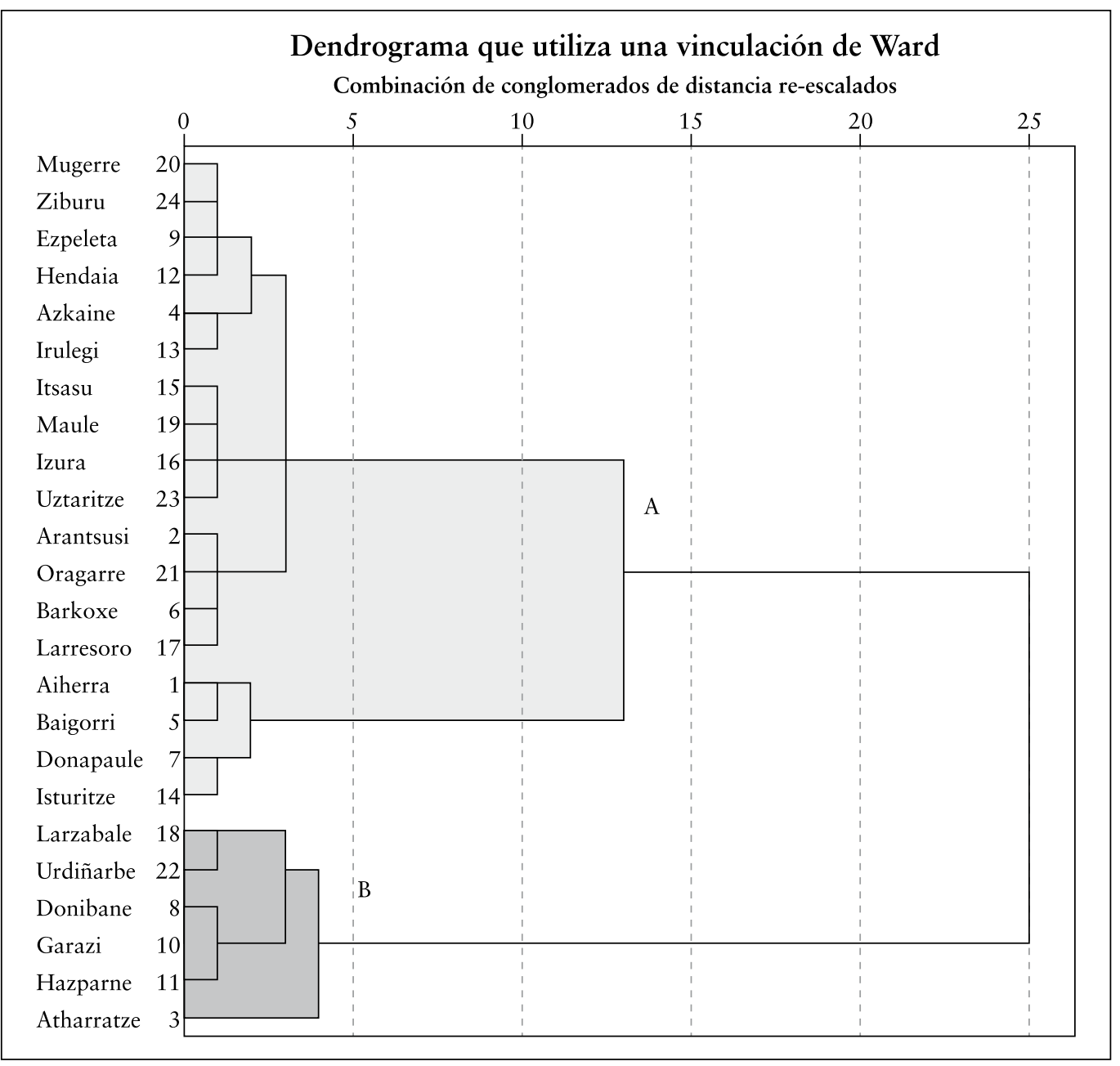

38. irudia. A taldeko nesken sailkapena dardarkari ubularraren alofonoen erabileraren arabera. 
Multzo bakoitzeko informatzaileak probintziaka sailkatuta ematen ditugu 22. taulan; A multzoan 6 informatzaile kokatzen dira (\% 25) eta B multzoan 18 (\% 75).

22. taula. A taldeko nesken sailkapena talde bitan, dardarkari ubularraren alofonoen erabileraren arabera.

\begin{tabular}{|l|l|l|}
\hline Multzoa & Probintzia & \multicolumn{1}{|c|}{ Informatzaileak } \\
\hline A & Lapurdi & Azkaine, Ezpeleta, Hedaia, Itsasu, Larresoro, Mugerre, Uztaritze eta Ziburu \\
\hline & Nafarroa & Aiherra, Arhantsusi, Baigorri, Donapaleu, Irulegi, Isturitze, Izura eta Oragarre \\
\hline & Zuberoa & Barkoxe eta Maule \\
\hline B & Lapurdi & Donibane eta Hazparne \\
\hline & Nafarroa & Garazi eta Larzabale \\
\hline & Zuberoa & Atharratze eta Urdiñarbe \\
\hline
\end{tabular}

39. irudiko mapan multzo bakoitzaren hedadura geografikoa erakusten da, bertan ikusten den bezala ez dago zonalde argirik.

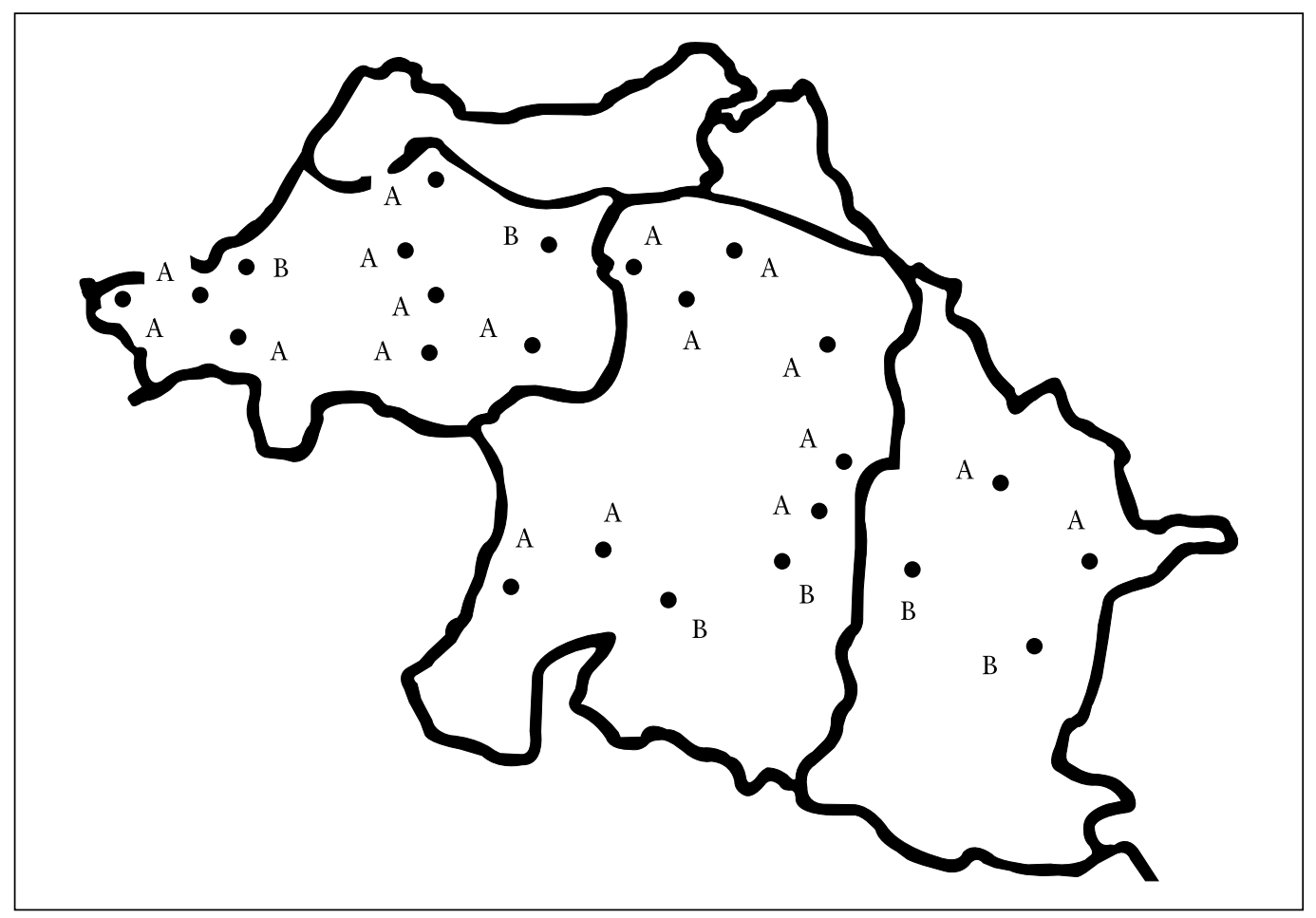

39. irudia. A taldeko nesken sailkapenaren hedadura geografikoa, dardarkari ubularraren alofonoen erabileraren arabera.

Alofonoen agerpenak informatzaileen generoaren arabera aztertuta, 23. taulako kopuruak eta ehunekoak lortzen dira; ehunekoetan agertzen diren aldeak ez dira estatistikoki esanguratsuak. 
23. taula. Alofonoen kopuruak eta ehunekoak informatzaileen generoaren arabera.

\begin{tabular}{|l|c|c|c|c|}
\hline \multicolumn{3}{|c|}{ Neskak } & \multicolumn{2}{c|}{ Mutilak } \\
\hline D1 & kop & $\%$ & kop & $\%$ \\
\hline D2 & 33 & 29,46 & 9 & 30 \\
\hline D3 & 54 & 48,21 & 17 & 56,67 \\
\hline Guztira & 25 & 22,32 & 4 & 13,33 \\
\hline
\end{tabular}

Datuak informatzaileen ama hizkuntzaren arabera aztertuta, 24. taulako kopuruak eta ehunekoak lortzen dira; ehunekoetan agertzen diren aldeak ez dira estatistikoki esanguratsuak.

24. taula. Alofonoen kopuruak eta ehunekoak informatzaileen ama hizkuntzaren arabera.

\begin{tabular}{|l|c|c|c|c|}
\hline \multicolumn{2}{|c|}{ A } & \multicolumn{2}{c|}{ B } \\
\hline D1 & kop & $\%$ & kop & $\%$ \\
\hline D2 & 33 & 29,46 & 11 & 35,48 \\
\hline D3 & 54 & 48,21 & 17 & 54,84 \\
\hline Guztira & 25 & 22,32 & 3 & 9,68 \\
\hline
\end{tabular}

\section{ONDORIOAK}

Azken atal honetan datuen azterketan lortu ditugun ondoriorik garrantzitsuenak bilduko ditugu. Lehenengo eta behin esan behar da dardarkari anizkunak gazteen erabileretan guztiz banatuta agertzen direla; Hegoaldean apikaria erabiltzen da eta Iparraldean ubularra.

Dardarkari apikarian agertu zaizkigun alofonoak zazpi izan dira, eurak hiru multzo nagusitan bana daitezke; multzo batean hertsigune bitik gora daukatenak bildu ditzakegu, hauetan hiru mota agertu zaizkigu: [r2], [r3] eta [r4], bakoitzak dauzkan hertsigune kopuruaren arabera. Beste multzo batean hertsigune bakarra daukaten alofono bi dauzkagu; batean hertsigunearen ostean bokal unea agertzen da [ [..I] eta bestean hertsigunearen ostean bokal unearekin batera zarata agertzen da $[\widetilde{r}[]$. Azkenik alofono hurbilkariak direnak dauzkagu; kasu honetan mota bi bereizi ditugu, batetik hertsiguneak agirian dauzkatenak $\left[\mathrm{r}_{\mathbf{r}} 2\right]$ eta bestetik hertsiguneak argi ez dauzkatenak $[\mathrm{r}]$.

Iraupenak balio du euren artean bereizteko, izan ere, lehen multzokoak luzeagoak dira gainerakoak baino, gainera zenbat eta hertsigune gehiago eduki orduan dardarkaria luzeagoa da. [r2] alofonoaren kasuan lehen hertsigunea eta bokal unea luzeenak 
izaten dira, aldea estatistikoki esanguratsua izanik. Hertsigune bakarreko alofonoak laburrenak izaten dira.

Energia osoak ez du balio alofonoen artean bereizkuntzarik egiteko. Hertsigune bakarreko alofonoen kasuan bereizketa egin daiteke energiaren aldearen arbera, izan ere, beherengo puntutik amaiera arteko energiaren aldea handiagoa da [r.I] suan $[\widehat{\mathrm{r}} \mathrm{I}] \mathrm{renean}$ baino.

Alofonoen erabileraren hedaduran, eragina daukan eragile linguistiko bakarra talde prosodikoen abiadura izan da, ikusi dugun moduan lehen multzoko alofonoak gehiago erabiltzen dira abiadura motelagoa denean, hots, badirudi abiadura motelak laguntzen duela artikulazioaren zehaztasunean eta ondorioz hertsigune gehiago agertzen da gauzapenean. Geografiak badauka nolabaiteko eragina alofonoen erabileraren hedaduran, izan ere, zonalde batzuk ondo zedarriturik agertu zaizkigu.

Generoa eragile garrantzitsua da alofonoen erabileran lehen multzoko alofonoekin neskek kopuru handiagoa erabiltzen dute mutilek baino; mutilek beste multzoekin erabilera handiagoa egiten dute; alde hauek estatistikoki esanguratsuak izan dira. Alta, informatzaileen ama hizkuntzak ez dauka eraginik.

Dardarkari ubularraren erabileretan beste hiru alofono multzo aurkitu ditugu. Lehen multzoan dardarkari ubularrak ikusi ditugu, bata $[\mathrm{R}]$ eta bestea $[\underset{\mathrm{R}}{\mathrm{R}}]$. Bigarren multzoan frikari ubularrak ikusi ditugu: $[\mathrm{ь}],[\underset{\mathrm{\zeta}}{ }]$ eta $[$ бъ]. Azkenik, hirugarren multzoan bien arteko ezaugarriak biltzen dituen alofonoa dugu, berori adierazteko $[\widehat{\mathrm{R}} \mathrm{\sigma}]$ erabili dugu.

Ikusi dugun moduan, iraupena erabil daiteke hirugarren multzokoak bereizteko, besteak baino luzeagoa delako. Energia adierazle ona izan daiteke lehen multzokoak bereizteko, izan ere, kontsonantearen erdialdean energia altuagoa edukitzen dute besteek baino. Era berean, hirugarren multzokoek energia altua daukate kontsonantearen hasierako gunean eta apalagoa bigarren gunean.

Alofonoen hedaduran aurreko kontsonante motak eragina dauka; horrela, dardarkari ubularrak gehiagotan agertzen dira aurreko silaban kontsonanterik ez dagoenean, frikariak, ostera, gehiagotan agertzen dira atzeko kontsonanteekin. Aurreko silabaren bokalek ez daukate eraginik eta talde prosodikoaren eragina nahikoa txikia dela esan dezakegu.

Geografiaren arabera ez dugu ikusi, Hegoaldean ez bezala, zonalde argirik. Gauza bera gertatzen da informatzaileen generoari eta ama hizkuntzari dagokienez. 


\section{ERREFERENTZIAK}

Blecua, B. (2001). Las vibrantes del español: manifestaciones acústicas y procesos fonéticos. Doktorego tesia, Bartzelona: Universidad Autónoma.

Blecua, B. (2008). Los sonidos vibrantes: aspectos comunes y variación. Language Design. Journal of Theoretical and Experimental Linguistics, Special Issue 1, New Trends in Experimental Phonetics, 23-30.

Boersma, P. \& Weenink, D. (2016). Praat: doing phonetics by computer, version 5.1. [computer program]. Hemendik hartua: http://www.praat.org

Bradley, T. G. \& Willis, E. W. (2011). Rhotic variation and contrast in Veracruz Mexican Spanish. Estudios de Fonética Experimental, XXI, 43-74.

Chambers, J. K. \& Trudgill, P. (1994). La dialectología. Madril: Visor.

Demolin, D. (2001). Some phonetic and phonological observations concerning /R/ in Belgian French. R-atics. Sociolinguistic, phonetic and phonological characteristics of /r/, Etudes \& Travaux, 4, 63-73.

Epelde, I. (2014). Akerrak adarrak okerrak edo dardarkarien gauzatzeaz. Hemendik hartua: https://31eskutik.com/2014/04/09/akerrak-adarrak-okerrak-edodardarkarien-gauzatzeaz/

Euskaltzaindia. (2008). Euskararen Herri Hizkeren Atlasa I. Bilbo: Euskaltzaindia, Euskadiko Kutxa.

Fernández Planas, A. M. (2013). Fonética acústica y experimental. Las vocales. Las glides y las consonantes sonantes en la cadena hablada. In M. ${ }^{a}$ A. Penas (arg.), Panorama de la fonética española actual (291-320 orr). Madril: Arco Libros.

Gaminde, I. (1998). Euskaldunen azentuak. Bilbo: Labayru Ikastegia.

Gaminde, I. (2006). Dardakarien ezaugarri akustikoez. Euskalingua, 8, 75-82.

Gaminde, I. (2007). Bizkaian zehar. Euskararen ikuspegi orokorra. Bilbo: Mendebalde Kultura Alkartea.

Gaminde, I., Romero, A., Eguskiza, N. \& Etxebarria, A. (2016). Dardarkari bakunaren alofonoez testu irakurrietan. Fontes Linguae Vasconum, 121, 121-140.

Hambye, Ph. (2005). La Prononciation du Français Contemporain en Belgique: Variation, normes et identités. Doktorego tesia, Université Catholique de Louvain. Hemendik hartua: http://dial.uclouvain.be/pr/boreal/fr/object/ boreal\%3A4883/datastream/PDF_01/view

Hualde, J. I. (2003). Segmental Phonology. In J. I. Hualde; J. Ortiz de Urbina, (arg.), A Grammar of Basque (15-33 orr.). Berlin: Mouton de Gruyter.

Hualde, J. I., Ortiz De Urbina, J. (2003). A Grammar of Basque. Berlin: Mouton de Gruyter.

Ladefoged, P., Maddieson, J. (1996). The sounds of the world's languages. Oxford: Blackwell.

Lyko, K. (2008). Segment data. Copyright 10.08.2008 Klaus Lyko.

Mitxelena, K. (1977). Fonética histórica vasca. Donostia: Gipuzkoako Foru Diputazioa.

Montoya, E. (2004). Urdazubi eta Zugarramurdiko Euskara. Iruñea: Nafarroako Gobernua. 
Oñederra, M. L. (2004). Fonetika fonologia hitzez hitz. Bilbao: Euskal Herriko Unibertsitatea.

Ortiz De Pinedo, N. (2012). Las vibrantes del español en habla espontánea. Phonica, 8, 44-67.

Pagola, R. M. (1992). Euskal fonetika Nafarroan I-II. Iruñea: Nafarroako Gobernua.

Penas, M. ${ }^{a}$ A. (2013). Panorama de la fonética española actual. Madril: Arco/Libros S. L.

Quilis, A. (1988). Fonética acústica de la lengua española. Madril: Gredos.

Quilis, A. (1993). Tratado de fonología y fonética españolas. Madril: Gredos.

Txillardegi (1980). Euskal fonologia. Donostia: Ediciones Vascas.

Zuazo, K. (1998). Euskalkiak gaur. Fontes Linguae Vasconum, 78, 191-234. 
0000 